http://dx.doi.org/10.12775/szhf.2018.031

JERZY KOPANIA

Akademia Teatralna im. A. Zelwerowicza, Warszawa, Polska

E-MAIL: JERZYKOPANIA@O2.PL

\title{
Leibniz i jego Bóg. Rozważania z Voltaireem w tle
}

\author{
Wprowadzenie
}

Jedynym narzędziem, którym może posługiwać się filozof, jest jego rozum. Przyrodnik ma wiele instrumentów służących do obserwacji, mierzenia i ważenia badanych rzeczy i zjawisk, ale filozof nie może się nimi posłużyć, gdyby bowiem zaczął ich używać, byłby przyrodnikiem. Filozof może jedynie komentować, interpretować lub z moralnego punktu widzenia oceniać wyniki badań naukowych, tym samym jednak sytuując się wobec naukowca na pozycji ubogiego krewnego. Dlatego wielki filozof wierzy niezłomnie, że posługując się własnym rozumem, może stworzyć system ukazujący i wyjaśniający istotę rzeczywistości. Gottfried Wilhelm Leibniz był wielkim filozofem, o czym świadczy stworzony przez niego wielki system filozoficzny. Podstawą tego systemu jest Bóg, a punktem wyjścia dwie zasady: racji dostatecznej i niesprzeczności. Za pomocą tych dwu zasad Leibniz stwarza swego Boga - wiecznego i niezmiennego jak one, zdeterminowanego nimi i dzia- 
łającego w ich ramach. Leibniz stworzył Boga na obraz i podobieństwo własnego umysłu ${ }^{1}$.

Staje się to widoczne w świetle krytyki dokonanej przez Voltaire’a. Logicznemu pojęciu Leibnizowskiego Boga przeciwstawił Voltaire w istocie swoje własne odczucie niemożności zrozumienia sensu ludzkiej egzystencji, doświadczenie ograniczoności ludzkiego rozumu. Bóg Leibniza jest na miarę genialnego umysłu filozofa; Voltaire nie jest zdolny pojąć tego Boga, jako że ma tylko zwyczajny, ludzki umysł. Bóg Leibniza to twór genialnego umysłu wielkiego filozofa - idea zawierająca w swej treści wszystkie doskonałości, której jednak nie przysługuje realne istnienie. Bóg taki, jakim go stworzył Leibniz, nie istnieje; można jedynie uznać, że niektóre z właściwości przypisanych Bogu przez Leibniza rzeczywiście są przejawami nieskończonej natury Boga Prawdziwego. Voltaire wie o tym, choć raczej należałoby powiedzieć, że to czuje, lub że tak mu podpowiada jego intuicja. Dlatego Voltaire nawet nie próbuje stwarzać Boga na swój obraz i podobieństwo - zresztą nawet gdyby chciał, to jego umysł nie podołałby zadaniu.

Leibniz miał niezachwianą wiarę w moc własnego rozumu. Dostrzegał oczywiście, że ten rozum jest ograniczony, czyli nie może wykroczyć poza ściśle określone ramy, jednak ograniczenie to nie jest rozumowi narzucone w taki sposób, że można by je było (teoretycznie) usunąć, lecz konstytuuje ono samą istotę rozumu, czyli bez niego rozum nie byłby rozumem. To ograniczenie rozumu, wyrażające jego istotę, przejawia się w jego działaniu, a więc ukazuje także jego naturę $e^{2}$ Można je zaś opisać w formie dwu zasad: racji dostatecznej i sprzeczności. Pierwsza z nich głosi, że „żaden fakt nie może okazać się rzeczywisty, czyli istniejący, żadna wypowiedź prawdziwa, jeżeli nie ma racji dostatecznej, dla której to jest takie, a nie inne"3. Na mocy drugiej zasady „osądzamy jako fałszywe to, co jest sprzecznością objęte, i jako praw-

\footnotetext{
${ }^{1}$ W niniejszych rozważaniach umysł to ogół władz duchowych człowieka, czyli sfera myślenia, woli i emocji. Rozum natomiast to umysł działający w sferze myślenia i woli.

${ }^{2}$ Istota danej rzeczy jest tym, bez czego rzecz ta nie byłaby tą właśnie rzeczą. Natura danej rzeczy to ogół jej cech i właściwości, dzięki którym jest ona taka, jaka jest, i działa w sobie właściwy sposób.

${ }^{3}$ Gottfried Wilhelm Leibniz, Zasady filozofii, czyli monadologia, $\$ 33$, tłum. Stanisław Cichowicz, w: Gottfried Wilhelm Leibniz, Wyznanie wiary filozofa. Rozprawa Metafizyczna. Monadologia. Zasady natury i łaski oraz inne pisma filozoficzne, tłum. Stanisław Cichowicz, Juliusz Domański, Henryk Krzeczkowski, Henryk Moese, oprac. Stanisław Cichowicz (Warszawa: PWN, 1969), 303. W Teodycei Leibniz używa też zamiennie określenia „racja rozstrzygająca”.
} 


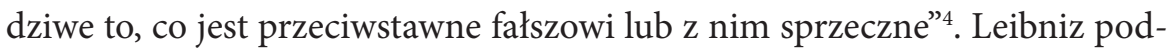
kreśla, że na tych dwóch wielkich zasadach opierają się nasze rozumowania; one też stanowią szkielet konstrukcji, którą Leibniz nazwał Bogiem.

\section{Bóg, czyli racja absolutna}

Zasada racji dostatecznej może być wyrażona w pewnym uproszczeniu jako teza, iż każdy skutek ma swoją przyczynę. Uproszczenie na tym polega, że przyczyna traktowana jest $\mathrm{w}$ istocie jako czynnik jeden i jednorodny. Postawmy pytanie, co jest przyczyną zaistnienia tego oto młodego dębu, który rośnie na polanie. Możemy odpowiedzieć, że tą przyczyną jest rosnący niedaleko stary dąb, który wydał z siebie owoc (żołądź) zawierający nasienie, z którego wyrosło młode drzewko. Ale dlaczego nie uznać, że to właśnie żołądź jest przyczyną? A może właśnie zawarte w nim nasionko? Jeszcze wyraźniej widać problem, gdy zapytamy o przyczynę zaistnienia tego oto człowieka. Można odpowiedzieć, że jest nią jego ojciec, ale przecież nie dokonałby tego bez matki. A zatem może, analogicznie jak w wypadku żołędzia, przyczynowość sprawczą należy przypisać łącznie plemnikowi ojca i jajeczku matki? Nasuwa się wniosek, że faktycznie mamy do czynienia nie z jedną przyczyną sprawczą, lecz z wielością czynników, które razem doprowadzają do zaistnienia danej rzeczy lub zajścia danego zjawiska.

Stara, arystotelesowska koncepcja przyczyny sprawczej, zgodnie z którą przyczyną sprawczą rzeźby jest rzeźbiarz, od wieków budziła rozmaite wątpliwości i rozmaicie była interpretowana. Leibniz mówi wprawdzie o „racji dostatecznej”, co sugeruje jakieś głębsze rozumienie przyczynowania, ale często powołuje się na „uznany aksjomat, że nic nie jest bez racji, czyli że żaden

${ }^{4}$ Leibniz, Zasady filozofii, czyli monadologia, $\$ 31$, 303. W swej polemice z Clarkiem Leibniz określa zasadę sprzeczności zwięźlej: „dany sąd nie może być jednocześnie prawdziwy i fałszywy"; Leibniz, Wyznanie wiary filozofa, tłum. Juliusz Domański, 325. Tak samo w Teodycei $(\$ 44)$. Zasada sprzeczności zwana jest także zasadą niesprzeczności lub zasadą tożsamości. Niektóre wypowiedzi Leibniza (np. z Nowych rozważań dotyczących rozumu ludzkiego, I, 1) zdają się wskazywać, że rozróżnia on między zasadą sprzeczności a zasadą tożsamości. Interpretatorzy na ogół sądzą jednak, że wedle Leibniza ta druga zawiera się w tej pierwszej. É. Boutroux w swym wydaniu Monadologii powiada lapidarnie: „Mais il est clair que, pour lui, le principe d'identité rentre dans le principe de contradiction"; Leibnitz, La Monadologie (Paris: Delagrave, 1880), 157-158, przypis 2. 
skutek nie jest bez przyczyny"5, co sugeruje tożsamość owej racji i przyczyny. Zarazem wyraźnie i wprost uzasadnia tę zasadę jej zdroworozsądkową oczywistością: „bo jedną z największych zasad zdrowego rozsądku jest przecież to, że nic nie dzieje się nigdy bez przyczyny lub określającej racji”'. Można zatem sądzić, że Leibniza utożsamienie przyczyny sprawczej z racją bierze się ze szczególnego rozumienia przyczyny sprawczej, takiego mianowicie, zgodnie z którym przyczyna sprawcza jest zarazem przyczyną celową. Nie znaczy to, że każda przyczyna sprawcza świadomie działa celowo, lecz że pierwsza i ostateczna przyczyna sprawcza świadomie i celowo ustaliła raz na zawsze stały porządek i sposób działania przyczynowo-skutkowego we wszechświecie, a zatem dla każdego skutku jego przyczyna jest zarazem racją jego zaistnienia. A świadomie i celowo działająca pierwsza i ostateczna przyczyna sprawcza to po prostu Bóg - dla Leibniza było oczywiste, że jest to Bóg-Osoba chrześcijańskiego Objawienia. W Teodycei tak oto odniósł się do postawionego przez Bayle’a zarzutu, że doskonałość organizacji materialnego wszechświata nie ma swego odpowiednika w organizacji świata duchowego.

Pan Bayle nie postawiłby tego zarzutu, gdyby znał opracowany przeze mnie system powszechnej harmonii, który głosi, że królestwo przyczyn sprawczych i królestwo przyczyn celowych są wzajemnie równorzędne, że Bogu przysługuje zarówno godność najlepszego monarchy, jak godność największego architekta, że materia została przygotowana tak, aby prawa ruchu służyły najlepszemu zarządzaniu duchami i że dlatego odsłoni się osiągnięte przez Boga możliwie największe dobro, o ile uwzględnimy jednocześnie dobro metafizyczne, fizyczne i moralne ${ }^{7}$.

Leibniz utożsamia przyczynę sprawczą z przyczyną celową, ponieważ jest przeświadczony, że usunięcie przyczyn celowych z fizyki czyni z Boga jedynie bezosobową siłę sprawczą. Jak pisze w Rozprawie metafizycznej, rezygnacja z przyczyn celowych w fizyce prowadzi z konieczności do uznania, „jak gdyby Bóg, działając, nie miał na względzie żadnego celu ani dobra lub jak gdyby dobro nie było przedmiotem jego woli"'. Leibniz natomiast dobrze

${ }^{5}$ Leibniz, Prawdy pierwotne metafizyki, tłum. J. Domański, w: Leibniz, Wyznanie wiary filo$z o f a, 88$.

${ }^{6}$ Leibniz, List do p. Coste’a, tłum. S. Cichowicz, w: Leibniz, Wyznanie wiary filozofa, 271-272.

${ }^{7}$ Leibniz, Teodycea, tłum. Małgorzata Frankiewicz (Warszawa Wydawnictwo Naukowe PWN, 2001), 345. Podobnie pisał do Clarke'a; zob. Leibniz, Wyznanie wiary filozofa, 412.

${ }^{8}$ Leibniz, Rozprawa metafizyczna, tłum. S. Cichowicz, $₫$ XIX, w: Leibniz, Wyznanie wiary filozofa, 121. 
wie, że Bóg jest bytem osobowym, choć z pewnością nie jest to wiedza uzyskana ani dzięki fizyce, ani dzięki filozofii - filozofia ma ją jedynie uzasadnić. Po prostu filozof nie ma wątpliwości, że „tu właśnie należy szukać zasady wszystkich istnień oraz praw natury, ponieważ Bóg ma zawsze na względzie to, co najlepsze i najdoskonalsze".

Zasada racji dostatecznej jest więc zarazem zasadą powszechnej celowości. Rzeczywistość jawi się jako swoista jedność materialno-duchowa, której każdy element istnieje w powiązaniu przyczynowo-skutkowym $\mathrm{z}$ wszystkimi innymi elementami. Całość rzeczywistości tworzy więc konieczną jedność i pełnię, mimo iż żaden element składający się na nią nie istnieje $\mathrm{z}$ konieczności. Leibniz konkluduje: „Trzeba zatem poszukiwać racji istnienia świata, który jest całościowym połączeniem przygodnych rzeczy; trzeba jej poszukiwać w substancji, która przynosi ze soba racje swojego istnienia, toteż jest konieczna i wieczna" ${ }^{10}$. Powszechne obowiązywanie zasady racji dostatecznej dowodzi istnienia Boga i umożliwia zrozumienie praw rządzących światem ${ }^{11}$. Pojawia się jedynie pytanie, na jakiej podstawie przyjmujemy, że zasada racji dostatecznej jest konieczna i powszechna. Leibniz zdaje się odpowiadać, że odrzucając tę zasadę, nie możemy sensownie myśleć o świecie. Dopiero sto lat później Immanuel Kant zauważy, że z tego, iż nie możemy inaczej myśleć o świecie, nie wolno nam wyprowadzać wniosku, iż świat jest taki właśnie, jak o nim myślimy. Ale zastrzeżenia pojawiły się już wcześniej.

Całkiem inne odczucie rzeczywistości miał Voltaire. Nie potrafił dostrzec owej pełni, wzajemnego powiązania i harmonii wszechrzeczy, która tak jasno i wyraźnie - rzec by się chciało: po kartezjańsku - jawiła się Leibnizowi. Oczywiście wie, że od najdawniejszych czasów ludzie przypuszczali, iż wszystkie zdarzenia wiążą się ze sobą, a w minionym stuleciu przekonanie to uzasadniał Leibniz. Ale w swoim Słowniku filozoficznym podejmuje (w haśle „Łańcuch zdarzeń”) polemikę i przypuszczenie to odrzuca jako bezpodstawne. Przyznaje, że każdy skutek ma swoją przyczynę, jednak twierdzi, że na tej tylko podstawie nie można utrzymywać, jakoby wszystko było $\mathrm{z}$ wszystkim powiązane.

\footnotetext{
9 Tamże.

${ }^{10}$ Leibniz, Teodycea, 124-125.

11 „Bez tej wielkiej zasady nie moglibyśmy nigdy udowodnić istnienia Boga oraz stracilibyśmy niezliczoną ilość bardzo słusznych i bardzo użytecznych rozumowań, których jest podstawą"; Leibniz, Teodycea, 155. Podobnie pisał do Clarke’a: „Ośmielam się rzec, iż bez tej wielkiej zasady nie można dowieść istnienia Boga ani uzasadnić wielu innych ważkich prawd”; Leibniz, Wyznanie wiary filozofa, 413.
} 
Zrozumiejmy się: każdy skutek ma oczywiście swoją przyczynę, jeśli cofamy się od przyczyny do przyczyny w otchłań wieczności, jednakże nie każda przyczyna ma swój skutek, jeśli iść będziemy aż do końca wieków. Przyznaję, że wszystkie zdarzenia są powodowane jedne przez drugie, a skoro przeszłość rodzi teraźniejszość, to teraźniejszość rodzi przyszłość; wszystko ma [swoich] ojców, ale nie wszystko zawsze ma dzieci. [...] Tak więc zdarzenia obecne nie są dziećmi wszystkich zdarzeń przeszłych: mają swoje linie bezpośrednie, jednak tysiące małych linii bocznych do niczego im nie służą. Powtórzmy raz jeszcze: każdy byt ma swego ojca, ale nie każdy byt ma swoje dzieci ${ }^{12}$.

Już zresztą wcześniej odniósł się do tej kwestii w kontekście przyrodniczym. W Elementach filozofii Newtona, dziele mającym zaznajomić Francuzów z systemem fizyki Newtona, wypowiada się jasno i zdecydowanie:

Niewątpliwie, każdy byt we wszechświecie jest z wszechświatem związany; lecz nie każde działanie jakiegoś bytu jest przyczyną zdarzeń tego świata. [...] Bywają zdarzenia, które są zarazem przyczyną i skutkiem. Lecz tysiące działań są tylko skutkami bez następstw ${ }^{13}$.

Zdaniem Voltaire’a teza, że każdy skutek ma swoją przyczynę, znaczy tyle tylko, że zaistnienie każdego bytu i zajście każdego zdarzenia musi mieć swoją przyczynę. Jednak nie znaczy to, że każdy byt jest (musi być) przyczyną zaistnienia innego bytu i każde zjawisko wywołuje (musi wywołać) inne zjawisko - a tylko wtedy można byłoby twierdzić, że wszystko jest ze wszystkim powiązane, czyli rzeczywistość stanowi pełnię.

12 „Entendons-nous: tout effet a évidemment sa cause, à remonter de cause dans l'abîme de l'éternité; mais toute cause n'a pas son effet, à descendre jusquà la fin des siècles. Tous les événements sont produits les uns par les autres, je l’avoue; si le passé est accouché du présent, le présent accouche du futur; tout a des pères, mais tout n'a pas toujours des enfants. [...] Donc les événements présents ne sont pas les enfants de tous les événements passés: ils ont leurs lignes directes; mais mille petites lignes collatérales ne leur servent à rien. Encore une fois, tout être a son père, mais tout être n'a pas des enfants"; Voltaire, Dictionnaire philosophique (Paris: Éditions Garnier Frères, 1954), 104-105. Istnieje przekład polski: Voltaire, Słownik filozoficzny, tłum. M. Skrzypek (Warszawa: Fundacja Augusta hr. Cieszkowskiego, 2015), 110-112. Dajemy przekład własny, ponieważ akurat w tym fragmencie tłumaczenie M. Skrzypka jest niedokładne i przez to nieco mylące.

${ }^{13}$ Zob. Voltaire, Elementy filozofii Newtona, tłum. Helena Konczewska (Warszawa: PWN, 1956), 44-45. 
Wprawdzie Voltaire nie mówi tego, można jednak zinterpretować jego stanowisko następująco: z faktu, że każdy skutek ma swoją przyczynę, wolno wyprowadzić wniosek o istnieniu nieskończenie wielu ciągów przyczynowo-skutkowych, które mogą nawet wielorako się przecinać, jednak nie wolno wyprowadzać wniosku, że każdy element danego ciągu jest powiązany z wszystkimi innymi elementami wszystkich innych ciągów. W innym miejscu swego Słownika (w haśle „Przeznaczenie”) wyjaśnia, że wprawdzie chłop wierzy, iż grad spadł na jego pole przypadkowo, a więc mógł nie spaść, jednak filozof wie, że ten grad spadł z konieczności, ponieważ ze względu na poprzedzający go ciąg przyczynowo-skutkowy właśnie musiał spaść tu i teraz. I w tym kontekście Voltaire odrzuca twierdzenie Leibniza, że istnieją prawdy konieczne, czyli twierdzenia o tym, co istnieje i jest takie właśnie, ponieważ nie może nie istnieć lub być inne, oraz prawdy przypadkowe, czyli twierdzenia o tym, co mogłoby nie istnieć lub być inne. „Dziwne by było, gdyby jedna część tego świata pozostawała ustalona [raz na zawsze], a druga nie; gdyby część z tego, co się zdarza, musiała się zdarzyć, a inna część z tego, co się zdarza, nie musiała się zdarzyc'"14.

Leibniz mógłby słusznie sprostować, że nie głosi, jakoby w realnym świecie zdarzenia, które zaszły, mogły nie zajść, lecz twierdzi, że możliwe są światy, w których by one nie zaszły. Voltaire zapewne odpowiedziałby na to, że w takim razie nic nie stoi na przeszkodzie, aby uznać możliwość realnego istnienia wielości światów. Taka odpowiedź byłaby dla Leibniza nie do przyjęcia świat Leibniza musi być światem jedynym i stanowić pełnię, albowiem tylko taki świat został stworzony przez chrześcijańskiego Boga. Za św. Augustynem głosi Leibniz, że Bóg jest wewnętrznym nauczycielem człowieka, zapala w nas światło, dzięki któremu możemy Go poznać; jednak w procesie tego poznania człowiek inspirowany jest przez czynniki wobec niego zewnętrzne, przez nauczycieli zewnętrznych. „Wśród owych zewnętrznych nauczycieli są dwaj, którzy najlepiej rozbudzają wewnętrzne światło: księga Pisma Świętego i doświadczenie natury"15. Leibniz dzięki Pismu Świętemu wie, że Bóg stworzył świat i że ten świat jest dobry; a na podstawie własnej interpretacji lub dzięki dominującej tradycji uznaje, że Bóg stworzył tylko jeden świat. Voltaire uważał Biblię za twór całkowicie ludzki i nie czuł się zobowiązany

\footnotetext{
14 „Il serait plaisant qu'une partie de ce monde fût arrangée, et que l'autre ne le fût point; qu'une partie de ce qui arrive dût arriver, et qu'une autre partie de ce qui arrive ne dût pas arriver"; Voltaire, Dictionnaire philosophique, 166.

${ }^{15}$ Leibniz, Pisma z teologii mistycznej, tłum. Małgorzata Frankiewicz (Kraków: Wydawnictwo Znak, 1994), 14.
} 
uzgadniać swoich przemyśleń z jej treścią. Dlatego Voltaire mógł dopuszczać wielość istniejących światów, mógł zakładać wieczne istnienie świata, mógł nawet powątpiewać w konieczność istnienia Boga. Leibniz jest zdeterminowany w myśleniu poczuciem oczywistości pojęcia Boga w rozumieniu chrześcijańskim. Faktycznie powodem uznania zasady racji dostatecznej za warunek konieczny myślenia nie jest uznanie, że tylko dzięki niej możemy poznać istotę i naturę świata, lecz przekonanie, że prowadzi ona do poznania Boga. A czy można poznać istotę i naturę Boga? Tak, ale tylko wtedy, gdy się go uprzednio samemu stworzy.

Zasada racji dostatecznej jest dla Leibniza drogą prowadzącą do Boga ${ }^{16}$. Skoro wszystko, co istnieje, musi mieć rację swego istnienia, to i rzeczywistość jako całość będąca zorganizowaną pełnią musi ją mieć. Skoro zaś zasada racji dostatecznej jest zarazem zasadą powszechnej celowości, to racją zaistnienia świata musi być Byt absolutnie doskonały i działający w sposób celowy. „Ponieważ zaś wszystko jest ze sobą połączone, nie ma powodu, aby przyjmować więcej niż jedna przyczynę. Jej rozum to źródło istot, a jej wola to początek istnień" ${ }^{\prime 7}$. Jeżeli istnieje świat, to dlatego, że istnieje Racja istnienia świata; ale ta Racja istnieje w sposób konieczny, tzn. nie może nie istnieć; zatem nie może nie być Racją istnienia świata, tzn. nie mogłaby świata nie stworzyć. Można to rozumieć następująco: Bóg działa z konieczności, a ponieważ jest Stwórcą, to musiał świat stworzyć.

Zwrócono uwagę, że Bóg filozofów nowożytnych, w szczególności Bóg Descartes’a i Leibniza, jest Bytem, którego samą istotą jest być Stwórcą ${ }^{18}$. Tak pojęty Bóg musi koniecznie zrobić to, co zrobić może, czyli działa z konieczności. Leibniz protestował przeciwko takiemu rozumieniu. „Z koniecznością absolutną miesza się konieczność moralną, wynikającą $\mathrm{z}$ wyboru tego, co najlepsze; z mocą Bożą miesza się wolę. Bóg może wytworzyć wszystko, co możliwe, lub to, co nie implikuje sprzeczności; jednakże chce wytworzyć

${ }^{16}$ Ten swój tok myślenia prowadzący od racji do Boga, a od Boga do doskonałości stworzonego świata przedstawił Leibniz bardzo esencjonalnie w rozprawce $O$ zasadach istnienia; zob. Leibniz, Wyznanie wiary filozofa, 225-228.

${ }^{17}$ Leibniz, Teodycea, 125.

${ }_{18}$ Zob. Étienne Gilson, Bóg i filozofia, tłum. Maria Kochanowska (Warszawa: Pax, 1982), 72. Gilson wyjaśnia, że Bóg chrześcijański jest oczywiście Stwórcą, jednak bycie Stwórcą nie jest Jego istotą - Bóg istnieje nie dlatego, że stwarza, lecz stwarza dlatego, że istnieje. Bóg stwarza, ponieważ chce stwarzać, a więc byty istnieją, ponieważ „Ten, który jest” udzielił im istnienia z własnej woli, nie zaś przymuszony jakąkolwiek koniecznością. 
to, co spośród możliwości najlepsze” ${ }^{19}$. Bóg działa zatem nie z konieczności, lecz mocą wyboru. Jednak wyjaśnienia Leibniza nie wszystkim wydały się przekonujące, co pokazała polemika Leibniza z Newtonem. Do tej dyskusji odniósł się Voltaire i jego rozumienie sporu wielce jest pomocne w rozumieniu zaistniałych rozbieżności.

Dyskusja Leibniza z Newtonem, prowadzona za pośrednictwem Samuela Clarkea, jest sporem o zasady organizacyjne świata. Jednak dla dyskutantów oczywiste było, że sposób działania rzeczy i zjawisk to w istocie sposób działania Boga w świecie. Dlatego Leibniz, przedstawiając swoje stanowisko, podkreśla znaczenie zasady racji dostatecznej, dzięki której dowodzi istnienia Boga oraz „pozostałych twierdzeń metafizyki czy też teologii naturalnej, a nawet $\mathrm{w}$ pewnej mierze zasad fizyki niezależnych od matematyki, tzn. zasad dynamiki czy siły"20. Punktem wyjścia dyskusji staje się więc zasada racji dostatecznej, co Clarke uznaje, ale zwraca uwagę na pewien jej aspekt, który ukazuje zasadniczą różnicę stanowisk.

Prawda to oczywista, że nie ma niczego bez dostatecznej racji, dla jakiej to istnieje i dla jakiej jest raczej takie niż inne. Tak więc, gdzie nie ma przyczyny, nie ma skutku. Częstokroć jednak ta wystarczająca racja jest niczym innym jak prostą wolą Boga. Na przykład: dlaczego dany system materii miałby zostać stworzony w danym miejscu, inny zaś w innym, podczas gdy vice versa dałoby ten sam skutek, albowiem wszelkie miejsce jest zupełnie obojętne dla każdej materii, zakładając, że oba systemy materialne (lub ich cząsteczki) są podobne. Przyczyna może być tylko jedna, a mianowicie prosta wola Boża. Jeśliby wola Boża nie mogła działać w żadnym przypadku bez przyczyny predeterminującej, $[. .$.$] wówczas należałoby wykluczyć jakąkolwiek możliwość wyboru$ i wprowadzić fatalnośćc 21 .

Clarke jest więc wprawdzie daleki od przypuszczenia, jakoby działanie Boga mogło być działaniem podjętym bez świadomego celu, ale zaprzecza, jakoby Bóg zawsze, w każdym akcie swego działania, musiał to właśnie, a nie jakieś inne działanie podjąć. Gdyby każde działanie Boga było dla niego samego jedynym możliwym, wówczas Bóg byłby bytem zdeterminowanym, nie zaś wolnym - twierdzi Clarke. Dlatego angielski teolog uważa, że Bóg jako

\footnotetext{
${ }^{19}$ Leibniz, Wyznanie wiary filozofa, 398; jest to fragment z polemiki z Clarke'iem.

${ }^{20}$ Tamże, 326.

${ }^{21}$ Tamże, 331.
} 
byt absolutnie wolny podejmuje także działania, których racją wystarczającą jest wyłącznie jego niczym nie uwarunkowana wola ${ }^{22}$.

Leibniz odnosząc się do powyższego, stwierdził, że stanowisko Clarke’a świadczy, że nie zrozumiał on właściwie zasady racji dostatecznej.

Zarzuca mi się, że nie przyjmując zgoła tej prostej woli Boga, trzeba byłoby odebrać Bogu możność wyboru i przystać na fatalność. Dzieje się jednak wręcz przeciwnie, możność wyboru zostaje przy Bogu, gdyż się ją zasadza na racji wyboru stosownej dla jego mądrości. Unikać natomiast trzeba nie tej fatalności (która nie jest niczym innym, jak porządkiem ustanowionym przez mędrca najwyższego czy też przez Opatrzność), ale fatalności lub też ślepej konieczności, gdzie nie ma już mowy ani o mądrości, ani o wyborze ${ }^{23}$.

Wedle Leibniza wybór dokonywany przez Boga jest zawsze jedynym wyborem możliwym nie dlatego, że innych możliwości nie ma, lecz dlatego, że każdy inny wybór byłby gorszy, a nieskończona mądrość Boga wybiera zawsze to, co lepsze, nigdy to, co gorsze ${ }^{24}$. Ale wedle Clarke’a to właśnie znaczy, że mądrość determinuje Boga, niejako pozbawia Go wolności. Aby tę Bożą wolność ocalić, Clarke przyjmuje, że muszą zachodzić sytuacje, w których wybór dokonywany jest spontanicznie, ponieważ każdy inny wybór również byłby przyczyną tego samego skutku i równie skutecznie do niego prowadził.

Różnica poglądów w tym się więc zasadza, że Clarke przyjmuje istnienie przyczyn nieodróżnialnych co do swych skutków, Leibniz natomiast je neguje. Dlatego Clarke uznaje możliwość dokonania niczym nie zdeterminowanego aktu woli, Leibniz natomiast możliwość taką odrzuca. Odpowiadając w kolejnym liście na uwagę Leibniza, Clarke powtarza: „W rzeczach z natury swej bezwzględnie jednakowych i niezróżnicowanych wola Boża może swobodnie wybierać i postanawiać bez żadnej zewnętrznej przyczyny, która by ją do tego

${ }^{22}$ Clarke w oryginale angielskim swego listu używa określenia the mere will, czyli „sama, niczym nie uwarunkowana wola"; zob. A Collection of Papers which passed between the Late Learned Mr. Leibnitz and Dr. Clarke..., by Samuel Clarke, printed for James Knapton, London 1717, 39. W przekładzie polskim oddano ten zwrot jako „prosta wola”, co jest bezpośrednim tłumaczeniem sformułowania francuskiego la simple volonté de Dieu, którym posłużył się Leibniz w odpowiedzi; zob. tamże, 62.

${ }^{23}$ Leibniz, Wyznanie wiary filozofa, 338.

${ }^{24}$ Dlatego w odniesieniu do Boga zasada racji dostatecznej jest zarazem zasadą wyboru najlepszej i najdoskonalszej z możliwości; zob. Stephen Grover, „West Or Best? Sufficient Reason in the Leibniz-Clarke Correspondence", Studia Leibnitiana 28 (1) (1996): 84-92. 
skłaniała; o doskonałości Bożej świadczy, że może to robić”25. Na to Leibniz ripostuje: „Prosta wola, bez żadnego motywu jest fikcją nie tylko przeciwną doskonałości Bożej, lecz nadto chimeryczną i sprzeczną, niezgodną z definicją woli i wystarczająco obaloną w Teodycei" ${ }^{26}$. Dalsze uwagi polemistów na ten temat już niczego nowego nie wprowadzają - jedynie utwierdzają czytelnika w przekonaniu, że to, co dla Leibniza stanowi istotę absolutnie wolnej woli Boga, dla Clarke'a (i Newtona) byłoby absolutnym zdeterminowaniem Boga $^{27}$.

Voltaire relacjonując bardzo skrótowo ten spór, sprowadza jego istotę do kwestii, czy istnieją rzeczy (sytuacje) obojętne, jak sądzą newtonianie, czy nie istnieją, jak sądzą leibnizjanie ${ }^{28}$. Ale nie podaje explicite rozwiązania. Wprawdzie podjął to zagadnienie w dziele «poważnym», jednak nie byłby sobą, gdyby powstrzymał się od lekkiej choćby ironii: „Pozostawiamy to do zbadania inteligentnemu czytelnikowi; długo będzie on rozważał to pytanie,

\footnotetext{
${ }^{25}$ Leibniz, Wyznanie wiary filozofa, 345.

${ }^{26}$ Tamże, 346. Leibniz rozważał ten problem w wielu miejscach swej Teodycei, wyrażając przekonanie, że mamy naturalne przeświadczenie, iż coś zawsze z czegoś się bierze: „Chcieć, aby określona decyzja wynikała z pełnej i całkowicie nieokreślonej obojętności, to chcieć, aby pochodziła po prostu z niczego"; Leibniz, Teodycea, 403. Dlatego twierdził stanowczo, że „nigdy nie ma obojętnej równowagi, czyli stanu, w którym wszystko jest zupełnie jednakowe, i nic bardziej nie skłania w jakimś kierunku”; tamże, 156. Jeżeli zdaje się nam, że podejmujemy jakąś decyzję bez jakiejkolwiek przyczyny, to dlatego, że po prostu nie znamy tej przyczyny, na przykład "gdy wychodzimy z pokoju, istnieje wiele powodów, które skłaniają nas, aby nie zastanawiając się nad tym, postawić najpierw jedną mogę"; tamże.

${ }^{27}$ Leibniz jeszcze przed dyskusją z Clarke’iem poruszył kwestię przyczyn nieodróżnialnych co do swych skutków w Liście do p. Coste’a (zob. Leibniz, Wyznanie wiary filozofa, 269-274), w nawiązaniu do słynnego przykładu osła Buridana, którym posłużył się Bayle, twierdząc, że człowiek może dokonywać wyborów także w sytuacjach równoważnych. Leibniz stanowisko Bayle’a odrzuca, twierdząc, że „przypadek doskonałej równowagi jest czymś chimerycznym i nie zdarza się nigdy”; tamże, 272. Arthur O. Lovejoy wskazuje, że jeśli takie sytuacje istnieją, to Bóg Leibniza nie mógłby w nich w ogóle zadziałać, ponieważ nie miałby racji dokonania wyboru. Dlatego Clarke przyjmując istnienie takich sytuacji, musi przyjąć zarazem możliwość działania niczym nie uwarunkowanej woli Boga, Leibniz natomiast musi obstawać przy twierdzeniu, że takie sytuacje nigdy nie zachodzą. „Twierdzenie to było oczywiście trudne do udowodnienia, przeto wysoce nieprawdopodobne. Leibniz uwikłany był w ten kłopot za sprawą nazbyt prostej i quasi-mechanistycznej koncepcji woli [...]. Gdzie nie było żadnej przewagi wartości w jednym z dwóch rozważanych przedmiotów, myślący podmiot pozostawał tak bezsilny i nieruchomy jak kawałek materii w równowadze sił"; Arthur Oncken Lovejoy, Wielki łańcuch bytu. Studium z dziejów idei, tłum. Artur Przybysławski (Warszawa: Wydawnictwo KR, 1999), 196.

${ }^{28}$ Zob. Voltaire, Elementy filozofii Newtona, 18-21.
} 
zanim zdoła sąd o tym sobie wyrobić"29. Zapewne inteligentny czytelnik ma się domyślić, że sprawa jest beznadziejna. Jeśli tak, to warto postawić pytanie, dlaczego jest beznadziejna. Otóż odpowiedzi na to pytanie udziela sam Leibniz, gdy wyjaśnia Clarke’owi: „Bóg nigdy nie jest określony przez rzeczy zewnętrzne, lecz zawsze przez to, co się w nim samym znajduje, zanim jeszcze cokolwiek jest na zewnątrz niego, to znaczy przez własną wiedzę ${ }^{\prime 30}$. Znaczy to po prostu tyle, że Bóg jest determinowany przez siebie samego. Leibniz uznał, że teza ta wyraża absolutną wolność Boga, Clarke zaś, że pełne zdeterminowanie. I każdy z nich był przekonany, że wyłożył racje rozstrzygające na rzecz swojego stanowiska.

\section{Bóg, czyli niesprzeczność absolutna}

Druga wielka zasada, którą kieruje się Leibniz, to zasada sprzeczności. Jej definicję filozof podawał wielokrotnie, ale zwróćmy uwagę na określenie zawarte w Nowych rozważaniach dotyczących rozumu ludzkiego, będących dyskusją z poglądami Locke’a.

Zasada sprzeczności mówi ogólnie: $z$ danie jest prawdziwe albo fałszywe, co zawiera dwie wypowiedzi prawdziwe: jedną, że prawdziwość i fałszywość nie moga się zejść w tym samym zdaniu, czyli że zdanie nie może być równocześnie prawdziwe i fałszywe; [oraz] drugą, że przeciwieństwo czy negacja prawdy i fałszu nie dają się pogodzić albo że nie ma niczego pośredniego między prawdą i fałszem, albo też: jest rzecza niemożliwa, aby jakieś zdanie nie byto ani prawdziwe, ani fałszywe. Otóż wszystko to jest tak samo prawdą we wszystkich dających się pomyśleć zdaniach w szczególności ${ }^{31}$.

Na podstawie powyższego opisu można by sądzić, że zasada sprzeczności jest jedynie zasadą naszego myślenia wyznaczającą ramy, poza które rozum

\footnotetext{
${ }^{29}$ Tamże, 21. Wszelako już bez ironii część poświęconą metafizyce Newtona kończy stwierdzeniem, że to czytelnik ma rozsądzić spór między Newtonem a Leibnizem; zob. tamże, 59. Oczywiście cały tok wywodów nie pozostawia wątpliwości, po której stronie tego sporu jest sam Voltaire.

${ }^{30}$ Leibniz, Wyznanie wiary filozofa, 350.

${ }^{31}$ Leibniz, Nowe rozważania dotyczące rozumu ludzkiego, tłum. Izydora Dąmbska (Warszawa: PWN, 1955), t. II, 151.
} 
ludzki wyjść nie może. Leibniz podkreślał, że bez zasady sprzeczności nie można się obejść w geometrii ${ }^{32}$, co mogłoby potwierdzać przypuszczenie, że nadaje jej sens czysto logiczny, tzn. rozumie ją jako zasadę determinującą sposób naszych rozumowań. To przypuszczenie potwierdzałby też fakt, że równie ważna jest dlań retoryczna użyteczność tej zasady, mianowicie bez niej nie jest możliwe dyskutowanie ${ }^{33}$.

Jednak takie rozumienie zasady sprzeczności byłoby ograniczające, jako że Leibniz wyróżnia dwa jej aspekty: aspekt logiczny i aspekt metafizyczny. Zasada sprzeczności określa nie tylko naturę ludzkiego myślenia, ale także naturę świata, a mianowicie nie tylko nie możemy myśleć nie respektując tej zasady, ale także nie może fizycznie zaistnieć nic, co by jej przeczyło. W dyskusji z Clarkiem Leibniz mówi wprost, że zasada sprzeczności wyznacza istotę rzeczywistości.

Jakoż w Teodycei wystarczająco wykazałem, że ta konieczność moralna jest zbawienna, zgodna $\mathrm{z}$ doskonałością Boską, a także $\mathrm{z}$ wielką zasada istnienia, tzn. z zasadą nieodzowności racji dostatecznej, gdy tymczasem konieczność absolutna i metafizyczna zależy od innej wielkiej zasady naszych rozumowań, tzn. od zasady istoty, czyli zasady tożsamości lub sprzeczności; to bowiem, co jest w sposób absolutny konieczne, jest jedynym rozwiązaniem możliwym spośród innych, a przeciwieństwo jego implikuje sprzecznośćc ${ }^{34}$.

Określając zasadę sprzeczności mianem zasady istoty, Leibniz zwraca uwagę na jej ontyczny aspekt, czyli na jej rolę w procesach dokonujących się we wszechświecie - zasada istoty ogranicza nie tylko nasze procesy myślowe, ale także wszelkie zjawiska zachodzące $\mathrm{w}$ świecie, a więc nie może fizycznie zaistnieć nic, co byłoby wewnętrznie sprzeczne.

Leibniz poświęca o wiele więcej uwagi zasadzie racji dostatecznej niż zasadzie sprzeczności, i o wiele częściej się na nią powołuje. Jest to niewątpliwie konsekwencją tego, że omawiane przezeń problemy są natury ontycznej, ale też bierze się z nastawienia na cel rozważań, czyli na uzasadnienie, iż istnieje

${ }^{32}$ Zob. tamże, t. II, 235.

${ }^{33}$ Zob. tamże, t. II, 242.

${ }^{34}$ Leibniz, Wyznanie wiary filozofa, 372. Czym są wskazane dwa rodzaje konieczności, Leibniz wyjaśniał Clarke’owi następująco: „Trzeba rozróżniać konieczność absolutną i konieczność hipotetyczną. Trzeba także rozróżniać konieczność, która ma miejsce dlatego, że przeciwieństwo implikuje sprzeczność, a zwie się koniecznością logiczną, metafizyczną czy matematyczną, i konieczność, która jest moralna i sprawia, że mędrzec wybiera to, co najlepsze, i że wszelki umysł postępuje za największą skłonnością"; tamże, 370 . 
Bóg będący ostateczną racją wszechrzeczy; można też jednak domniemywać, że Leibnizowi zasada sprzeczności wydała się tak oczywista w płaszczyźnie myślenia, że niejako mimowolnie uznał ją za oczywistą także w płaszczyźnie bytowej. Jednak kwestia bynajmniej oczywista nie jest. Zauważmy bowiem, że nie jest jasne, na czym polegać by miała wewnętrzna sprzeczność rzeczy, czyniąca niemożliwym jej zaistnienie. Jest to proste w przypadku desygnatów pojęć abstrakcyjnych i dobrze rozumiemy, że nie może zaistnieć np. kwadratowe koło. Nie jest to natomiast proste w przypadku desygnatów terminów teoretycznych, czyli takich terminów, które wprawdzie należą do jakiejś teorii empirycznej, jednak ich konotację stanowią cechy nie dające się obserwować zmysłowo. Czy na przykład istnieją atomy rozumiane jako byty fizyczne? Leibniz możliwość taką zdecydowanie odrzucał: „Nie istnieje atom, a co więcej, żadne ciało nie jest tak drobne, żeby nie mogło być aktualnie podzielne" ${ }^{35}$. Gdy stanowisko swe wyraził w polemice z Clarkiem, ten zareagował ostro: „p. Leibniz głosząc niemożliwość atomów fizycznych [...] głosi jawną niedorzeczność" ${ }^{36}$. Clarke nie tylko sądzi, że nie jest niemożliwe, aby istniały niepodzielne cząsteczki, ale wygłasza mocną tezę: „Jeżeli [...] nie ma w materii doskonale trwałych części, to nie ma też we wszechświecie mate-

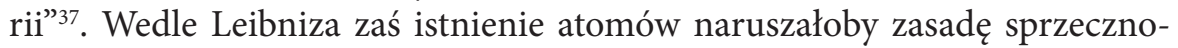
ści, ponieważ atomy byłyby zarazem nieodróżnialne jako niepodzielne, czyli doskonale jednakowe, oraz odróżnialne, skoro dawałoby się stwierdzić ich wielość; dlatego dla Leibniza jest oczywiste, że „nie ma dwóch przedmiotów indywidualnych doskonale jednakowych i że muszą one różnić się czymś więcej, aniżeli numero" ${ }^{\prime 3}$. Jednakże odpowiadając Clarke’owi, nie odwołuje się do zasady sprzeczności, tylko do zasady racji dostatecznej, twierdząc, że to właśnie zapominanie o niej jest źródłem „chimer, jakimi są na przykład czas czy przestrzeń absolutna i rzeczywista, próżnia, atomy [...] oraz tysiące innych fikcji”39.

\footnotetext{
${ }^{35}$ Tamże, 92.

36 Tamże, 368.

37 Tamże, 369.

${ }^{38}$ Leibniz, Nowe rozważania dotyczace rozumu ludzkiego, t I, 18. W innym miejscu Leibniz powiada, że gdyby istniały atomy Demokryta, to „nie byłoby też wtedy zgoła różnicy między dwoma różnymi indywiduami tego samego kształtu i tej samej wielkości”; tamże, t. II, 32.

${ }^{39}$ Tamże, 413. Zauważmy w tym miejscu, że Newtona teza o istnieniu absolutnej przestrzeni i absolutnego czasu była przedmiotem zasadniczej krytyki ze strony Leibniza. To zagadnienie dominuje w jego korespondencji z Clarkiem, a swoje stanowisko Leibniz uzasadnia odwołując się głównie do zasady racji dostatecznej; zob. Elhanan Yakira, „Time and Space, Science and Philosophy in Leibniz-Clarke Correspondence", Studia Leibnitiana 44 (1) (2012), 14-32.
} 
To znamienne, że argumentując przeciwko istnieniu atomów Leibniz woli odwoływać się do zasady racji dostatecznej. Wprawdzie podkreśla, że „atom nie godzi się z rozumem ni z ładem, zawiera wszak już aktualne części, z których się składa" ${ }^{\prime 0}$, ale nacisk kładzie na wskazywanie, że dzięki zasadzie racji dostatecznej poznajemy, iż świat jest pełnią, w której wszystko ze wszystkim jest powiązane, a więc panuje w niej ład, który nie jest niczym innym, ,jak stosunkiem najbardziej uwydatniającym różnorodność"41, podczas gdy zamęt na tym polega, że „nie ma racji rozróżnienia czegokolwiek” ${ }^{42}$. I to właśnie rozstrzyga o nieistnieniu atomów: „To przeczy istnieniu atomów i w ogóle ciał, w których nie ma żadnych racji dla rozróżnienia jakiejkolwiek części”43. Kwestia ta zwróciła uwagę Voltaire’a, który pod adresem Leibniza i jego zwolenników taki kieruje zarzut:

Przyjmujecie materię aktualnie podzielną w nieskończoność, a więc wykrycie najmniejszej cząstki tej materii jest niemożliwe; nie ma takiej, która nie miałaby boków, nie zajmowałaby miejsca w przestrzeni, nie miałaby pewnego kształtu: jakże więc chcielibyście, aby była utworzona wyłącznie $\mathrm{z}$ bytów bez kształtu, bez miejsca, bez boków? Czy nie naruszacie tu zasady niesprzeczności, chcąc uczynić zadość zasadzie racji dostatecznej? ${ }^{44}$

Voltaire czyni więc Leibnizowi zarzut niekonsekwencji. Otóż filozof neguje istnienie atomów jako niepodzielnych cząstek, ponieważ byty takie nie podlegałyby zasadzie racji dostatecznej (nie byłoby podstawy do zatrzymania podziału na tej właśnie, a nie innej części) i zasadzie sprzeczności (dwa atomy byłyby nieodróżnialne, a zarazem odróżnialne). Sam zaś przyjmuje podział materii w nieskończoność, ponieważ w ramach własnego systemu potrafi wskazać rację dostateczną tej nieskończonej podzielności, jednak nie zauważa, sądzi Voltaire, iż jest sprzecznością utrzymywać, że nie istnieją najmniejsze cząstki, a zarazem że każda cząstka ma właściwy sobie kształt.

\footnotetext{
${ }^{40}$ Leibniz, Wyznanie wiary filozofa, 165-166.

${ }^{41}$ Tamże, 227.

${ }^{42}$ Tamże.

${ }^{43}$ Tamże. Zob. także Nowe rozważania dotyczace rozumu ludzkiego, t. I, 287-288. Przeciwko istnieniu atomów Leibniz wysuwał również argument empiryczny: „Dwie krople wody lub mleka dadzą się rozróżnić, gdy są oglądane przez mikroskop. Jest to argument przeciwko atomom obalonym na równi z próżnią przez zasady prawdziwej metafizyki”; Wyznanie wiary filozofa, 347. Por. Nowe rozważania dotyczace rozumu ludzkiego, t. I, 125.

${ }^{44}$ Voltaire, Elementy filozofii Newtona, 55.
} 
Niejasna krytyka Voltaire’a nie przekonuje - w szczególności zarzut naruszenia zasady sprzeczności zdaje się opierać na tezie, że nieskończona podzielność (ciągłość) materii uniemożliwiałaby jednostkowienie bytów, która to teza jest co najmniej dyskusyjna ${ }^{45}$. Jednak dla niniejszych rozważań ważne jest nie to, czy Voltaire właściwie odczytał stanowisko Leibniza, lecz to, co stanowi istotę jego krytycyzmu. Otóż Voltaire zarzuca Leibnizowi, że obie zasady traktuje instrumentalnie, odwołując się do jednej z pominięciem drugiej, jeżeli w danym przypadku jest mu tak wygodniej. Można jednak wątpić, czy intelekt tej miary rzeczywiście świadomie pomija to, co mogłoby przeczyć uzasadnianej przezeń tezie ${ }^{46}$. Zarzuty Voltaire’a biorą się bardziej z odmienności postaw i w konsekwencji z odmienności języka niż z krytycznej analizy poglądów Leibniza. Zapewne dlatego Voltaire ogranicza się do przykładowego wskazania, co uważa za niekonsekwencję w stanowisku Leibniza, nie stawiając problemu, który przecież nasuwa się wyraźnie. Otóż zasada racji dostatecznej generowała problem, czy Bóg działa w sposób wolny, czy determinowany koniecznością, zasada sprzeczności natomiast rodzi pytanie, czy wszechmocny Bóg jest nią w swym działaniu ograniczony.

Zasady takie, jak zasada racji czy zasada sprzeczności uznaje Leibniz za wrodzone i tym samym stanowiące o naturze ludzkiego umysłu. „Zasady ogólne wchodzą w skład naszych myśli, których są duszą i więzią. Są tam tak konieczne, jak muskuły i ścięgna do chodzenia, mimo że o nich się nie

${ }^{45}$ Dla poznania stanowiska Leibniza ważne są dwa jego teksty. Pierwszy to rozprawka Disputatio metaphysica de principio individui z 1663 roku; istnieje przekład polski: Gottfried Wilhelm Leibniz, „Rozprawa metafizyczna o zasadzie indywiduacji”, tłum. Tomasz Gliński, Studia z Historii Filozofii 5 (3) (2014), 35-51. Drugi, wyrażający znacząco zmodyfikowane stanowisko, to Wyznanie wiary filozofa z 1673 roku. O ewolucji poglądów Leibniza na tę kwestię zob. Massimo Mugnai, „Leibniz on Individuation: From the Early Years to the „Discourse” and Beyon", Studia Leibnitiana 33 (1) (2001), 35-56. Zauważmy w tym miejscu, że Voltaire jest krytyczny także wobec Newtona, zarzucając mu niekonsekwencję, gdy przyjmując istnienie niepodzielnych cząstek, zarazem przyjmuje, iż nieustannie przemieniają się one jedne w drugie; zob. tamże, 51-53. Warto także poczynić uwagę, że poglądy Leibniza na naturę substancji przeszły na tyle znaczną ewolucję, że skłoniło to niektórych badaczy do uznania, iż w najwcześniejszym okresie swej twórczości był on atomistą. Teza ta jest jednak wątpliwa; zob. Krystyna Krauze-Błachowicz, Leibniz. Wczesne pojęcie substancji (Białystok: Zakład Teorii Poznania. Filia Uniwersytetu Warszawskiego, 1992), w szczególności strony 111-116.

${ }^{46}$ Co nie wyklucza możliwości nieświadomego naruszenia zasady sprzeczności, to zaś Leibnizowi się zdarzało. Na przykład twierdził, że siła fizykalna wpływa na wszystkie zjawiska świata materialnego, ale utrzymywał zarazem, iż siła fizykalna jest duszą, a dusza nie oddziałuje na świat materialny; zob. Mieczysław Gordon, „O krytyce przez Leibniza kartezjańskiej wersji dualizmu”. Studia Philosophiae Christianae 21 (1) (1985), 30, przypis 17. 
myśli’"47. Rozum nie może działać wbrew tym zasadom, a posługuje się nimi bez konieczności czynienia nad tym namysłu; Leibniz mówi nawet, że „posługujemy się nimi dzięki naturalnemu instynktowi”" ${ }^{48}$. Można powiedzieć, że zasada sprzeczności stanowi ramy, w których porusza się skończony ludzki umysł; jednak dla Leibniza było oczywiste, że stanowi ona także ramy nieskończonego umysłu Boga. Zasada sprzeczności wiąże Boga w niemniejszym stopniu, jak wiąże człowieka - a nawet Boga wiąże jakby mocniej, ponieważ dotyczy zarówno Jego myślenia, jak i Jego woli. Człowiek może myśleć błędnie, nie zauważając, że popada w sprzecznośćc ${ }^{49}$, Bóg natomiast nigdy nie błądzi; człowiek może żywić sprzeczne pragnienia, wola Boga jest determinowana Nim samym jako Dobrem ${ }^{50}$. Na mocy zasady racji dostatecznej Bóg z nieskończenie wielu możliwych światów dokonuje wyboru tego jedynego, najlepszego. Ale na mocy zasady sprzeczności wśród nieskończenie wielu możliwych światów nie ma żadnego, który byłby wewnętrznie sprzeczny, ponieważ tylko to jest możliwe, czego istnienie nie pociąga za sobą logicznej sprzeczności. Inaczej mówiąc, skoro myślenie Boga jest zarazem kreacją rzeczywistości, to nie ma i być nie może sprzeczności ani w Boskim myśleniu, ani w Boskim dziele stworzenia. Leibniz w istocie utożsamia Boga z pierwszymi zasadami. I analogicznie jak przy zasadzie racji dostatecznej można by podjąć dyskusję, czy zasada sprzeczności stanowi ograniczenie Boskiej wszechmocy. Tyle że ta dyskusja byłaby równie beznadziejna, jak tamta.

Teza, że zasada sprzeczności jest wyrazem natury Boga, a więc nie może być przez Niego pomyślane i tym samym nie może być przez Niego stworzone nic, co by ją naruszało, przewija się przez całą Teodyceę. Leibniz zakłada ją szczególnie w kontekstach rozważań nad nieskończoną mądrością

${ }^{47}$ Leibniz, Nowe rozważania dotyczace rozumu ludzkiego, t. I, 64.

${ }^{48}$ Tamże, t. I, 74.

${ }^{49}$ Por. wyżej, przypis 46. Zwrócono uwagę, że Leibnizowi zdarzało się głosić tezy niezgodne z wcześniej podawanymi. „U Leibniza spotyka się często twierdzenia sprzeczne. Tak też w odniesieniu do rachunku nieskończonościowego powiada: „Pomimo rachunku nieskończonościowego wcale nie przyjmuję czegoś naprawdę nieskończonego", jak również mówi: "Infinitum natura dari non dubio". Raz nazywa Spinozę człowiekiem o wyższej umiejętności sądzenia, acutissimum judicium, a siebie stałym jego wielbicielem, cultor sedulus, gdzie indziej zaś ma go za autora „nieznośnie rozpasanego, człowieka, który upadł tak nisko”. Kiedy to spostrzega, usprawiedliwia się z owych sprzeczności kładąc je na karb zapomnienia, tego, że pisał saltatim, że nie może zajrzeć do swych pism wcześniejszych"; Jean Guitton, Profile, tłum. Ada Borkowska-Szuba, Stanisław Cichowicz, Wanda Sukiennicka (Warszawa: Instytut Wydawniczy Pax, 1973), 135.

${ }^{50}$ Zob. np. Leibniz, Teodycea, 540. 
Boga, który zna wszystkie możliwości, m.in. dyskutując z Bayle’em, sugerującym, że Bóg mógłby lepiej ustalić pewne rzeczy, np. zbawić wszystkich ludzi.

Zgadzam się z zasadą pana Bayle’a, bo to również moja zasada, że wszystko, co nie pociąga za sobą sprzeczności, jest możliwe. Ale my utrzymujemy, że Bóg zrobił najlepsze, co mógł zrobić, czyli nie mógł zrobić lepiej, niż zrobił, oraz sądzimy, że inny pogląd o całości Jego dzieła oznaczałby obrazę Jego dobroci i Jego mądrości. Toteż według nas trzeba powiedzieć, że zrobienie jakiejś rzeczy, która przewyższa dobrocią nawet to, co najlepsze, pociąga za sobą sprzeczność. Podobnie byłoby, gdy ktoś twierdziłby, że Bóg może poprowadzić z jednego punktu do drugiego linię krótszą niż linia prosta i zarzucałby zaprzeczającym temu osobom obalanie artykułu wiary, zgodnie z którym wierzymy w Boga Ojca wszechmogącego ${ }^{51}$.

Zasada sprzeczności stanowi więc, obok innych zasad pierwotnych, wyznacznik Boskiej natury, jest zasadą determinującą zarówno Boski rozum, jak i Boską wolę, czyli jest jakby emanacją Boskiego umysłu. Bóg jest nieskończoną mocą, nieskończoną wiedzą, nieskończoną dobrocią i jako taki jest sam w sobie absolutną niesprzecznością. Leibniz często podkreślał, że „nieograniczenie mądry Bóg musi przestrzegać pewnych praw i działać zgodnie zarówno z fizycznymi, jak moralnymi zasadami, które wybrał dzięki swojej mądrości" ${ }^{2}$. Jednak nie chodzi mu tylko o to, że Bóg jest wierny własnym decyzjom, nigdy ich nie zmienia, a więc możemy mieć całkowitą pewność, że nie zmieni ani praw przyrody, ani zasad ludzkiego myślenia, ani danego nam poczucia moralności - Leibniz twierdzi, że Bóg nie może zmienić zasad działania wszechrzeczy, nie mógłby stworzyć rzeczywistości rządzonej innymi zasadami, a nawet nie mógłby chcieć tego uczynić. Jak w takim razie rozumieć należy tezę, że Bóg jest wszechmocny? Leibniz odpowiada: „Oznacza to, że Bóg może uczynić to [wszystko], co nie pociąga za sobą sprzeczności, do tego bowiem przede wszystkim sprowadza się pojęcie możliwości i niemożliwości” ${ }^{33}$.

Bóg jest więc determinowany zasadą racji dostatecznej i ograniczany zasadą niesprzeczności, co jednak zdaniem Leibniza nie tylko nie czyni Go zniewolonym i ograniczonym, lecz wręcz przeciwnie - świadczy o Jego absolutnej wolności. Jedynie Bóg jest absolutnie wolny, ponieważ jedynie On

\footnotetext{
${ }^{51}$ Leibniz, Teodycea, 328-329.

52 Tamże, 143.

${ }^{53}$ Leibniz, O wolności, przeznaczeniu i łasce Bożej, w: Leibniz, Pisma z teologii mistycznej, 169.
} 
jest absolutną racją istnienia i absolutną niesprzecznością. Absolutnie wolny Bóg Wszechmogący stworzył najlepszy z możliwych światów, a innego świata stworzyć by nie mógł. „Stąd z kolei wynika, że nie ma większego szczęścia niż służba Pańskiemu dobru, która polega na tym, że Boga trzeba kochać ponad wszystko i całkowicie mu ufać" ${ }^{54}$.

\section{Leibniz, czyli umysł stwarzający}

Z samego faktu, że stworzona przez Boga rzeczywistość jest taka właśnie i takimi oto rządzi się prawami, nie wynika jednak, iż Bóg nie mógł stworzyć innej rzeczywistości, z innymi prawami. Aby takie wynikanie zachodziło, potrzebna jest oczywiście dodatkowa przesłanka - teza, że taka, a nie inna jest rzeczywistość stworzona, ponieważ taka, a nie inna jest natura Boga. A przecież skłonni jesteśmy sądzić, że ani Leibniz, ani żaden inny człowiek, nie może mieć bezpośredniej wiedzy o naturze Boga. Faktycznie tok rozumowania Leibniza nie przebiega od natury Boga do natury rzeczywistości stworzonej, lecz w kierunku odwrotnym - ponieważ rzeczywistość stworzona jest taka właśnie, to z tego należy wnosić, jaka jest natura Boga. Leszek Kołakowski twierdzi, że wskazując zachodzenie swoistej tożsamości Boga oraz zasad logicznych i ontycznych, nie możemy kategorii bytu ludzkiego odnosić w tym samym sensie do bytu boskiego. „Gdy więc mówimy, że Bóg nie może na przykład unieważnić reguł logiki czy etyki, słowa 'nie może', jak zresztą wszystkie inne słowa, którymi posługujemy się przy opisywaniu Boga, mają znaczenie odmienne od ich potocznego sensu"55. Problem polega jednak na tym, że skoro do Boga nie odnoszą się słowa naszego języka, to albo dysponujemy jakimś innym językiem i w nim się wypowiadamy, albo konsekwentnie powinniśmy o Bogu milczećs ${ }^{56}$. Próbą uniknięcia tej trudności jest tzw. teologia apofatyczna, wedle której wszelkie nasze charakterystyki Bytu Boskiego mają charakter negatywny, tzn. w istocie mówią o tym, jaki Bóg nie jest. Jednak Leibniz określając Boga w kategoriach pozytywnych, nie

\footnotetext{
${ }^{54}$ Leibniz, Przyczyna pochodzaca od Boga, w: Leibniz, Pisma z teologii mistycznej, 101.

${ }^{55}$ Leszek Kołakowski, Jeśli Boga nie ma, tłum. Tadeusz Baszniak i Maciej Panufnik (Kraków: Wydawnictwo Znak, 1988), 27.

${ }^{56}$ „O czym nie można mówić, o tym trzeba milczeć”; Ludwig Wittgenstein, Tractatus logicophilosophicus, tłum. Bogusław Wolniewicz (Warszawa: PWN, 1970), 88. Jest to teza 7, kończąca Traktat.
} 
rozumie ich w jakimś negatywnym sensie. Jeżeli mówi o atrybutach Boga, to podkreśla, że mają one charakter absolutny, a możemy je pojmować, ponieważ pojęcie nieskończoności nie jest nam znane dzięki zmysłom, lecz z doświadczenia wewnętrznego, pochodzi z tego samego źródła co pojęcie prawd koniecznych.

Idea tego, co absolutne, jest wewnątrz nas tak samo, jak idea bytu. Te rzeczy absolutne nie są niczym innym jak atrybutami Boga i można orzec, że one nie mniej są źródłem idei, jak Bóg sam jest zasadą bytów ${ }^{57}$.

Leibniz charakteryzuje Boga tak, jakby dana mu była bezpośrednio wiedza o naturze Bytu Absolutnego. I w pewnym sensie ta wiedza jest mu dana - pochodzi bowiem z przyjętego przezeń implicite założenia, że umysł ludzki jest odbiciem czy odwzorowaniem w skali skończonej nieskończonego umysłu Boskiego, czyli że treść i zasady działania umysłu człowieka i umysłu Boga są identyczne co do swej istoty, a różnią się jedynie co do zakresu. Teza ta wydawała mu się zapewne tak oczywista, że nie dostrzegał potrzeby jej uzasadniania. Dziwne, że Voltaire nie dostrzegł, iż zachodzi pewna analogia między Leibnizem a człowiekiem, który na podstawie znajomości zasad działania zegara wnosiłby o naturze zegarmistrza.

Problem ludzkiej wiedzy o Bogu podjął Voltaire, rozważając kwestię, czy można pogodzić wolność naszych czynów $\mathrm{z}$ wieczną wiedzą antycypacyjną Boga. Uznał, że aby zagadnienie to rozwiązać, należałoby posiadać jakąś wiedzę o sposobach działania Boga, jednak taka wiedza pozostaje poza zasięgiem możliwości skończonego umysłu człowieka: „Wszystkie jego atrybuty są dla nas w równej mierze niezrozumiałe" ${ }^{\prime 8}$. A omawiając kwestię natury duszy i jej stosunku do ciała, powołuje się na Newtona, który wedle świadectwa Locke’a miał twierdzić, że „nasza znajomość Natury nie wystarcza, by ośmielić się twierdzić, iż dla Boga jest rzeczą niemożliwą udzielić daru myślenia jakiemukolwiek bytowi rozciągłemu" ${ }^{\prime 2}$. Do Locke’a zresztą żywi Voltaire szczególny szacunek między innymi dlatego, iż wyraźnie twierdził on, że nie jest rozsądne przyjmować, że wszechmocny Bóg czegoś nie może zrobić, na przykład nie może obdarzyć myślą bytu materialnego ${ }^{60}$. Nawet w swych $\mathrm{Pa}$ -

\footnotetext{
${ }^{57}$ Leibniz, Nowe rozważania dotyczace rozumu ludzkiego, t. I, 175.

${ }^{58}$ Voltaire, Elementy filozofii Newtona, 25.

59 Tamże, 37.

${ }^{60}$ Zob. tamże, 39. Voltaire opiera się na tym, co Locke pisał w Rozważaniach dotyczacych rozumu ludzkiego IV, 3, 6. Zauważmy, że Locke przeczył istnieniu zasad wrodzonych, nie mógł
} 
miętnikach poczynił wzmiankę: „Locke był bardzo mądry przyznając, że nie do nas należy decydowanie o tym, czego nie może zrobić Wszechmocny"61.

Podawane przez Voltaire’a przykłady są jedynie egzemplifikacjami ogólnej tezy, iż jest sprzecznością twierdzić, że Byt wszechmogący czegoś zrobić nie może. Wprawdzie Voltaire nie formułuje tej tezy wprost, jednak jest ona skrycie obecna w jego rozważaniach jako logiczna konsekwencja twierdzenia o niemożności poznania przez umysł ludzki zasad i metod działania Umysłu Nieskończonego.

Filozofia wykazuje nam niezawodnie, że Bóg istnieje, lecz niezdolna jest pouczyć nas, kim on jest, co czyni, jak i dlaczego czyni, czy istnieje w czasie, czy w przestrzeni, czy rozkazał raz jeden, czy też działa nieustannie, czy znajduje się w materii, czy też go w niej nie ma itd., itd. Trzeba by samemu być Bogiem, aby to wiedziećc ${ }^{2}$.

Faktycznie Voltaire zarzuca Leibnizowi, że ograniczając działanie wszechmocnego Boga granicami logiki, narusza zasadę sprzeczności, do której tak wielką wagę przywiązuje. Inaczej mówiąc, Voltaire obwinia Leibniza, że zachowuje się tak, jakby doskonale wiedział, jakie są atrybuty Boga. Ale w tym właśnie Voltaire popełnia błąd. Leibniz dobrze wie, jaka jest natura Boga sam Go przecież stworzył na swój obraz i podobieństwo, przydając $\mathrm{Mu}$ w stopniu nieskończonym wszystkie skończone przymioty własnej natury. Czynił to oczywiście nie z taką świadomością, lecz w najgłębszym przekonaniu, że myślą swoją dotyka Umysłu Bożego, i z poczuciem, że taka jest jego powinność. Pisał bowiem: „Wszystkie stworzenia służą szczęściu albo chwale Bożej stosownie do stopnia swojej doskonałości”63. A stopień doskonałości umysłu Leibniza musimy uznać za wyjątkowo wysoki ${ }^{64}$.

Już samo przekonanie, że człowiek może swym umysłem uchwycić naturę umysłu Boga, jest zadziwiające i kryje w sobie wyraźną sprzeczność, nie zauważaną jednak przez tych, którzy zasadę sprzeczności uznali za wyrażającą

więc twierdzić, że można poznać zasady, którymi kieruje się Bóg.

${ }^{61}$ Wolter, Pamiętniki, tłum. Stanisław Fiszer (Warszawa: Książka i Wiedza, 1994), 36.

${ }^{62}$ Voltaire, Elementy filozofii Newtona, 12.

${ }^{63}$ Leibniz, Definicje i twierdzenia etyczne, w: Leibniz, Pisma z teologii mistycznej, 223.

${ }^{64}$ Bertrand Russell ocenił, że Leibniz „jest jednym z najpotężniejszych umysłów wszech czasów"; tenże, Dzieje filozofii Zachodu (Warszawa: Fundacja Aletheia, 2000), 669. Zdanie zakończył jednak opinią, że ,jako człowiek nie wzbudza podziwu”; jego zdaniem bowiem Leibniz dla kariery dworskiej poświęcał prawdę filozoficzną. Do kwestii tej powrócimy; zob. niżej, przypis 78 . 
istotę wszechrzeczy. Oto skończony umysł ludzki uznaje, że jego natura jest także naturą nieskończoności. Jaka jest jednak podstawa tego przekonania? Leibniz nie stawiał takiego pytania - zafascynowany dokonywanymi w jego stuleciu odkryciami tego, co nieskończenie wielkie, i tego, co nieskończenie małe ${ }^{65}$, odkryciami dokonanymi przecież przez skończony ludzki rozum, odczuwał w sobie moc, która nie tylko pozwoliła mu stworzyć rachunek nieskończonościowy, ale także narzuciła przekonanie, że umysł Boga, stwarzając świat i utrzymując go w istnieniu, musi działać wedle zasad matematycznych. Cum Deus calculat et cogitationem exercet, fit mundus - napisał na marginesie jednego ze swych tekstów ${ }^{66}$. Przynajmniej w tym momencie nie miał wątpliwości, że rozum Boga jest rozumem matematycznym różniącym się jedynie co do mocy od rozumu ludzkiego; aby odczuć, czym jest umysł Boga, należało tylko przyjąć, że wolna wola człowieka jest odwzorowaniem niekończonej wolności woli Boga. Leibniz skonstruował nieskończony umysł Boga, mając za model swój skończony genialny umysł.

Ci, którzy zaprzeczają, jakoby można było orzekać o Bogu i Jego działaniach w terminach pozytywnych, po prostu nie mają genialnego umysłu. $\mathrm{Na}$ przykład Spinoza wiedział, jaka jest natura Boga (Deus sive Natura), ponieważ Spinoza był geniuszem; ale Voltaire geniuszem nie był, więc tego nie wiedział. A niemożność zdobycia pozytywnej wiedzy o naturze Boga wprawdzie nie przeczy możności zdobywania wiedzy o naturze rzeczy stworzonych, ale uniemożliwia uzyskanie odpowiedzi na ostateczne pytania egzystencjalne.

${ }^{65} \mathrm{O}$ tej fascynacji świadczy krótki tekst O podwójnej nieskończoności w naturze; zob. Leibniz, Wyznanie wiary filozofa, 277-279. Jest to komentarz do słynnego fragmentu 84 z Myśli Pascala (w układzie J. Chevaliera). Może warto wskazać, że tłumacz tego tekstu skorygował fragment swego przekładu przy okazji przekładu cytowanej już książki Guittona Profile; zob. tamże, 70, przypis 54.

${ }^{66}$ Chodzi o rozprawkę Dialogus z 1677 roku; zob. Carl Immanuel Gerhardt, red. Die Philosophischen Schriften von G. W. Leibniz. T. VII (Berlin: Weidmann, 1890), 190-193 (wskazanie dopisku na stronie 191). Istnieje przekład polski (z drobnymi opuszczeniami) w: Mieczysław Gordon, Leibniz (Warszawa: Wiedza Powszechna, 1974), 224-228, jednak bez zaznaczenia wskazanego dopisku (powinien być wskazany na stronie 226, wiersz 14 od góry). O swoistej jedności myślenia matematycznego i metafizycznego u Leibniza zob. Christia Mercer, "Leibniz on Mathematics, Methodology and the Good: A Reconsideration of the Place of Mathematics in Leibniz's Philosophy”, Early Science and Medicine 11 (4) (2006), 424-454. „His concern with theological matters (in particular his commitment that the world be a proper expression of God) encouraged his mathematical work, while his keen interest with infinitesimals and related matters informed his conception of divinely harmonized minds"; tamże, 441. 
„Stawiajmy na końcu wszystkich rozdziałów metafizyki dwie litery używane przez sędziów w Rzymie, kiedy nie wiedzą, o co chodzi: N. L., non liquet, to nie jest jasne" - powiada Voltaire ${ }^{67}$. Sceptyczny, daleki od genialności umysł Voltaire’a doprowadził go do wniosku, że o ostatecznych przyczynach wszechrzeczy wiemy tyle, ile dziecię w kołysce: nous sommes tous dans la même ignorance des premiers principes où nous étions dans notre berceau. ${ }^{68}$.

Leibniz faktycznie uznał, że umysł Boga podlega tym samym ograniczeniom co umysł człowieka. To z tym nie mógł zgodzić się Descartes: „moc Boga nie może mieć żadnych granic"69. Bóg nie jest ograniczony zasadą sprzeczności, ani żadną inną z tzw. prawd pierwotnych. Gdyby Bóg chciał, to mógłby np. sprawić, aby suma trzech kątów trójkąta nie była równa dwóm prostym. A dlaczego nie chciał? Otóż „nie powinniśmy starać się tego zrozumieć, ponieważ nasza natura nie jest do tego zdolna"70. Zdecydowane stanowisko Descartes’a było sprzeciwem wobec scholastycznej doktryny głoszącej, że pewnych rzeczy Bóg chce z konieczności, pewnych zaś nie może powołać do istnienia, ponieważ są one niemożliwe same w sobie. Tomasz z Akwinu wyjaśniał to na przykładzie działań matematycznych i logicznych. „Logik i matematyk rozważają rzecz jedynie w aspekcie zasad formalnych; stąd nie-

${ }^{67}$ Voltaire, Słownik filozoficzny, 70 (hasło „Dobrze. Wszystko jest dobrze”). Richard A. Brooks podkreśla, że Voltaire’a przez całe życie nękał problem zła, którego chrześcijańskie rozwiązanie odrzucał, a właściwego rozwiązania nie mógł znaleźć ani na gruncie deizmu, ani z pomocą prawa naturalnego; zob. Richard A. Brooks, Voltaire and Leibniz (Genève: Librairie Droz, 1964), 61-63. Metafizyka zaś nie mogła dostarczyć żadnego rozwiązania z tego zasadniczego powodu, że zdaniem Voltaire’a umysł ludzki jest niezdolny do radzenia sobie z kwestiami metafizycznymi; stąd jego skrajnie anty-metafizyczna postawa. „Man's inability to cope with the subtle, impractical problems of metaphysics was a theme to which Voltaire returned time and time again throughout his career. When he wrote on metaphysics, it was usually to attack it as a discipline, or to parody it, or to show its futility; tamże, 65 (zob. także strony 88 i 99).

${ }^{68}$ Voltaire, Le philosophe ignorant (Paris Éditions Flammarion, 2009), 31. Polski przekład fragmentów można znaleźć w: Bronisław Baczko, red., Filozofia francuskiego Oświecenia (Warszawa: PWN, 1961), 92-99.

${ }^{69}$ Descartes, List do Meslanda z 2 maja 1644 r., w: Jerzy Kopania, Szkice kartezjańskie (Kraków: Aureus, 2009), 217.

${ }^{70}$ Tamże, 218. „Nie ma [...] potrzeby dociekać tego, na jakiej zasadzie mógłby był Bóg odwiecznie uczynić, żeby nie było prawdą, że dwa razy 4 jest 8 itd.; przyznaję bowiem, że my tego zrozumieć nie możemy"; René Descartes, Medytacje o pierwszej filozofii, tłum. Maria i Kazimierz Ajdukiewiczowie i in. (Warszawa: PWN, 1958), t. II, 36 (tłum. Stefan Swieżawski). Zob. także list do Arnaulda, w: Descartes, Zarzuty i odpowiedzi późniejsze, tłum. J. Kopania (Kęty: Wydawnictwo Antyk, 2005), 46-47 oraz list do More’a, w: tamże, 58. Szerzej o Descartes’a rozumieniu Boga zob. Kopania, Szkice kartezjańskie, 68-76. 
możliwe jest dla nich tylko to, co jest przeciwne racji formalnej rzeczy. I to, co niemożliwe w taki sposób, zawiera w sobie sprzeczność, a zatem jest niemożliwe samo przez się. Otóż tak rozumianej niemożliwości Bóg nie może realizować"71. Inaczej mówiąc, sprzeczność stanowi ramy wszechmocy Boga. Twierdzenie to oparte jest na założeniu, że Bóg stwarza poznając, a poznaje za pomocą idei, przy czym idea jest w Bogu tym samym, co Jego istota. Dzięki temu można było sądzić, że poznając istoty rzeczy stworzonych, poznaje się $\mathrm{w}$ jakiejś przynajmniej mierze istotę $\mathrm{Boga}^{72}$.

To właśnie zakwestionował Descartes, argumentując, że Bóg stwarza wszystko, a zatem jest również stwórcą tzw. prawd wiecznych czy pierwszych zasad, ale ustalając jako prawdę wieczną np. to, że zdania sprzeczne nie mogą być oba prawdziwe, nie był niczym zdeterminowany. Nie mamy więc żadnych podstaw, aby twierdzić, że Bóg czegoś nie może, a jedynie wolno nam twierdzić, że Bóg nałożył pewne ograniczenia, a także wyznaczył zasady, odnoszące się do umysłu ludzkiego i do całej rzeczywistości stworzonej. Możemy nawet twierdzić więcej - że Bóg na samego siebie nałożył pewne ograniczenia w odniesieniu do człowieka i przyrody, dzięki czemu umysł ludzki może poznawać istotę rzeczy stworzonych. Nie może jednak poznać natury i istoty Boga. Descartes tak wyjaśniał Henry’emu Moreowi swą postawę: „Dlatego twierdzę śmiało, że Bóg może wszystko to, co ja pojmuję jako możliwe; nie ośmielam się natomiast [równie] śmiało twierdzić, że nie może On tego, co sprzeciwia się memu pojmowaniu, lecz powiadam tylko, że pociąga to za sobą sprzeczność" ${ }^{73}$. Stanowisko Descartes’a świadczy, że genialność jest wprawdzie warunkiem koniecznym, by filozof doszedł do przeświadczenia, iż ujął naturę Boga, ale nie jest warunkiem wystarczającym. Należy więc postawić pytanie, skąd bierze się ostrożność metodologiczna Descartesả, skąd zaś śmiałość poznawcza Leibniza.

Punktem wyjścia filozofii Descartes’a jest cogito - samoświadomość podmiotu, poczucie własnego istnienia nie podlegające najmniejszej choćby wątpliwości. Wszystko, co jawi się umysłowi bezpośrednio, każda myśl, musi więc być odniesione do świadomości samego siebie i w niej znajdować wszelkie uzasadnienie poznawcze. Inaczej rzecz ujmując: wszystko, co

\footnotetext{
${ }^{71}$ Tomasz z Akwinu, De potentia VI, 1, ad 11.

72 To zastrzeżenie, że w jakiejś tylko mierze, zdaje się nam ważne, ponieważ Tomasz nie twierdzi przecież, iż człowiek może pojąć Bożą istotę. Zwraca na to uwagę E. Gilson: „Metafizyka stawia Boga jako czysty Akt istnienia, ale nie daje nam żadnego pojęcia o Jego istocie. Wiemy, że On jest; ale nie pojmujemy Go"; Gilson, Bóg i filozofia, 108.

${ }^{73}$ List do More’a z 5 lutego1649, w: Descartes, Zarzuty i odpowiedzi późniejsze, 58.
} 
nie jest świadomością własnego istnienia podmiotu, wymaga dowodu swego istnienia; Descartes najpierw udowadniał, że istnieje Bóg, a następnie i dzięki temu, że istnieje świat. Substancję, w której bezpośrednio tkwi myślenie, nazywa Descartes umysłem; substancję, o której wiemy, że jest najdoskonalsza, i w której nie pojmujemy żadnego braku ani żadnego ograniczenia doskonałości, nazywa Bogiem ${ }^{74}$. Świadom samego siebie filozof znajduje w swym umyśle ideę Boga, czyli Najdoskonalszego Bytu Nieskończonego i Wszechmocnego, a usiłując rozumowo ująć naturę tego Bytu, jest zarazem świadom, że ujmuje zaledwie skończone ślady nieskończoności. Dlatego nie ośmiela się twierdzić, że ten Byt jest czymś (choćby samym sobą) ograniczony i z natury swej czegoś uczynić nie może.

Punktem wyjścia filozofii Leibniza jest poczucie tożsamości natury własnego umysłu z naturą Stwórcy tego umysłu. Bóg jawi się mu jako moc własnego umysłu zwiększona w nieskończoność, a więc jako Nieskończony Umysł, którego skończonym obrazem jest ludzki umysł. Nie ma zatem innej jak tylko co do zakresu różnicy między umysłem a Umysłem. Dlatego Leibniz ośmiela się sądzić, że odkrywa naturę Boga - naturę wyznaczoną tymi samymi co do istoty ograniczeniami jak jego umysł. A ponieważ umysł Leibniza jest umysłem genialnym, więc nie sprawia mu trudności argumentowanie, że ani ograniczenia te nie ujmują Bogu wszechmocy, ani takie rozumienie Boga nie narusza zasady sprzeczności.

Descartes czuł w sobie oczywistość własnego istnienia; Leibniz czuł w sobie oczywistość istnienia Boga ${ }^{75}$. Na podstawie samych tekstów Leibniza można domniemywać, że był człowiekiem głęboko wierzącym; ale wiarę swą pielęgnował w swym wnętrzu, rzadko ujawniając ją w publicznej przestrzeni

${ }^{74}$ Zob. zestaw definicji podany przez Descartes'a jako dodatek do Odpowiedzi na zarzuty drugie: Descartes, Medytacje o pierwszej filozofii, t. I, 198-200.

${ }^{75}$ Leibniz akceptuje kartezjańskie Cogito, ergo sum. Jednak rozumie je (a raczej: odczuwa) inaczej, mianowicie jako duszę, której funkcją jest zarówno odzwierciedlanie ciał, jak i działanie moralne, sam zaś związek duszy z ciałem jako jedność monadyczną. „Dusza podlega swoim własnym prawom, podobnie jak ciało podlega swoim; schodzą się zaś na mocy harmonii wprzód ustanowionej między wszystkimi substancjami, są one bowiem wszystkie przedstawieniami tego samego wszechświata”; Leibniz, Zasady filozofii, czyli monadologia, 313-314. Odrębną kwestię stanowi, czy zachodzi sprzeczność między duszą jako biernym zwierciadłem ciał i jako pierwotną siłą czynną; zob. Gordon, „O krytyce przez Leibniza kartezjańskiej wersji dualizmu", 29-30. Poczyńmy na marginesie uwagę, że Voltaire odrzucał Leibniza koncepcję harmonii wprzód ustanowionej nie tylko i może nawet nie przede wszystkim z powodów metafizycznych, „but because he also felt that man's liberty could not be reconciled with a pre-established harmony"; Brooks, Voltaire and Leibniz, 78. 
kościelnej. W Hanowerze miał opinię niedowiarka, do kościoła chodził bardzo rzadko, a jeszcze rzadziej przyjmował komunię. Jeden z pastorów nawiązując do nazwiska nazwał go Loevenix, co w języku dolnoniemieckim znaczy „Glaubt nichts”, czyli „w nic nie wierzący”. Jak podaje Gottschalk Eduard Guhrauer (1809-1854), autor jednej z najwcześniejszych biografii Leibniza $^{76}$, mówiono, że podobno na łożu śmierci odmówił przyjęcia komunii $^{77}$. Taka postawa wzbudzała podejrzenie, że nowatorska i trudna filozofia Leibniza to tylko pojęciowa gra umysłu, wyrafinowana rozrywka władców i arystokracji, autentyczne poglądy zaś filozof zachowuje dla siebie i ujawnia jedynie wybranym ${ }^{78}$. Dwanaście lat po śmierci filozofa, w 1728 roku, ukazała się publikacja, która zdawała się potwierdzać tę opinię ${ }^{79}$. Christopher Matthäus Pfaff (1686-1760) luterański teolog, autor m.in. dzieła Dissertationes

${ }^{76}$ Zob. G. E. Guhrauer, Gottfried Wilhelm, Freiherr v. Leibnitz. Eine Biographie, Breslau 1842, suplement 1846 (reprint: Georg Olms Verlag, Hildesheim 1966). Praca zawiera sporo ciekawych anegdot o Leibnizu. Istnieje angielska modyfikacja, którą sporządził z myślą o czytelniku amerykańskim John M. Mackie (1813-1894); zob. J. M. Mackie, Life of Godfrey William von Leibnitz; on the basis of the German work of Dr. G. E. Guhrauer, Boston 1845 (przedruki późniejsze: Kessinger Publishing, 2007 i Leopold Classic Library, 2015).

77 Zob. Benson Mates, The Philosophy of Leibniz. Metaphysics and Language (New York-Oxford: Oxford University Press, 1986), 16.

${ }^{78}$ Być może po raz pierwszy zaczęto tak sądzić po opublikowaniu przez Leibniza jego rozumienia transsubstancjacji; zob. Guitton, Profile, 136-137. Podzielał tę opinię Bertrand Russell: „To, co publikował, miało zaskarbić mu przychylność książąt i księżnych. Skutek tego taki, że istnieją dwa systemy filozofii, które można uważać za właściwy system Leibniza: jeden, który głosił otwarcie, jest optymistyczny, ortodoksyjny, fantastyczny i płytki; drugi, który stopniowo jest wydobywany na światło dzienne z manuskryptów, jest głęboki, spójny, mocno Spinozjański i zadziwiająco logiczny”; Bertrand Russell, Dzieje filozofii Zachodu, tłum. Adam Lipszyc, Tadeusz Baszniak i inni. (Warszawa: Fundacja Aletheia, 2000), 669. Tezę tę Russell wygłosił w wydanej w 1900 roku książce Critical exposition of the philosophy of Leibniz, pozostając pod wrażeniem świeżych odkryć nieznanych tekstów Leibniza. Zapoznawanie się z tymi tekstami bardziej skłaniało jednak do wniosku, że jest to problem znalezienia spójnej interpretacji, nie zaś sprawa dwóch niezgodnych systemów. Tak podchodzi do zagadnienia np. Robert Merrihew Adams: „Yet my principal concern is with the intrinsic rationale of his thought. I have made no general application of a hermeneutics of suspicion. Not that I think (nor would Leibniz himself have thought) that he was free of hidden and unconscious motives. On some points, the project of understanding his rationale itself requires some attention to suspicions of insincerity in his statements. In the end, however, Leibniz's reasons are more interesting than his motives"; Adams Robert Merrihew, Leibniz. Determinist, Theist, Idealist (New York - Oxford: Oxford University Press, 1994), 6. Dodajmy jednak, że motywy są ważne, jeśli pomagają zrozumieć racje.

${ }^{79}$ Zob. Adams, Leibniz. Determinist, Theist, Idealist, 50-52. 
Anti-Baelianae, będącego stanowczą krytyką poglądów i postawy Bayle’a, dobry znajomy Leibniza, zamieścił w Acta Eruditorum informację o wymianie poglądów z Leibnizem dotyczących Teodycei. Pfaff zapytał filozofa, czy to prawda, że jego zwalczanie sceptycyzmu Bayle’a jest tylko grą intelektualną, a w rzeczywistości podziela on w pełni poglądy francuskiego erudyty. Leibniz miał odpowiedzieć listem, datowanym 2 maja 1716 roku, którego następujący fragment Pfaff zamieścił: „Otóż tak właśnie jest, Wielce Czcigodny Panie, jak żeś o mojej Teodycei napisał. Trafiłeś w samo sedno. To zadziwiające, że nie znalazł się dotąd nikt, kto wyczułby, iż jest to tylko moja gra. Nie jest bowiem rzeczą filozofów zawsze do sprawy podchodzić poważnie, lecz poprzez wymyślanie hipotez, jak słusznie zauważyłeś, ćwiczą oni moc swego umysłu. Ty zaś, który jesteś teologiem, zwalczasz błędy teologów" ${ }^{80}$.

W autentyczność listu jedni wierzyli, inni jej zaprzeczali. Na przykład Pierre Desmaizeaux (ok. 1666 lub 1673-1745), francuski hugenota przebywający na wygnaniu w Londynie, korespondent Leibniza, wydawca w 1720 roku wyboru jego tekstów ${ }^{81}$, w słowie wstępnym do drugiego, poprawionego i rozszerzonego ich wydania z 1740 roku przytoczył w łacińskim oryginale i swoim francuskim przekładzie komunikat Pfaffa zawierający ów fragment z listu Leibniza $^{82}$. Zauważył od siebie, że wprawdzie wielu uczonych mężów, wśród nich Christian Wolff, uznaje te słowa za żart, ale przecież Wolff jako kontynuator filozofii Leibniza nie może być w tym wypadku neutralny. Jednak współcześnie raczej nie traktuje się tej odpowiedzi Leibniza dosłownie ${ }^{83}$. Przyjmuje się, że jest to po prostu ironiczna kpina ${ }^{84}$. Autentyczności listu bowiem nie

\footnotetext{
${ }^{80}$ „Ita prorsus est, Vir summe reverende, uti scribis de Theodicea mea. Rem acu tetigisti. Et miror, neminem hactenus suisse, qui lusum hunc meum senseris. Neque enim philosophorum est, rem serio semper agere, qui in fingendis hypothesibus, uti bene mones, ingenii sui vires experiuntur. Tu, qui Theologus es, in refutandis erroribus Theologum ages"; Acta Eruditorum anno MDCCXXVIII publicata, Lipsiae 1728, 127.

${ }^{81}$ Recueil de diverces pieces sur la philosophie, la religion naturelle, l'histoire, les mathematiques, etc., par Mrs Leibniz, Clarke, Newton et autres autheurs célebres, t. I i II, Amsterdam 1720.

${ }^{82}$ Zob. Recueil de diverces pieces..., Amsterdam 1740, t. I: Avertissement sur cette seconde Editon, strony nie numerowane.

${ }^{83}$ Do nielicznych badaczy traktujących odpowiedź Leibniza serio należy włoski filozof Edmondo Cione (1908-1965); zob. Edmondo Cione, Leibniz (Napoli: Libreria Scientifica Editrice, 1964), 40.

${ }^{84}$ Vittorio Mathieu w swym wstępie do włoskiego przekładu Teodycei pisze: „Come non capi, Pfaff, che Leibniz lo prendeva in giro? Era un sintomo d'ingenuità allarmente, in un uomo che si accingeva a discutere un autore cosi sottile e intelligente, anche se spesso superficiale, come Bayle"; V. Mathieu, Saggiointroduttivo. La conciliazione di ragione e fede punto culminante della
} 
kwestionuje się. Wprawdzie w materiałach Leibniza nie natrafiono na żaden jego ślad, ale niewiarygodne wydaje się, aby Pfaff go sfabrykowat ${ }^{85}$. Przyjmijmy zatem, że odpowiedź Leibniza na pytanie Pfaffa jest autentyczna i wyraża jego maskowane ironią oburzenie; wyrażenie oburzenia wprost byłoby sprzeczne $\mathrm{z}$ charakterem i dworskimi manierami filozofa. I zastanówmy się, jakie były rzeczywiste intencje pytającego. Włoski historyk filozofii Andrea Poma twierdzi, że w założeniu pytania Pfaffa zawarte jest przekonanie pytającego, iż Leibniz należy do tych filozofów, którzy odróżniając Boga filozofii od Boga wiary, maskują w ten sposób swoją niewiarę, a więc Leibniz publicznie krytykując Bayle’a, prywatnie podziela jego sceptycyzm. Leibniz tę podstępną sugestię odrzucił, za pomocą ironii wskazując, że jest ona fałszywa ${ }^{86}$.

A przecież ta sugestia zwraca uwagę na problem, z którego Pfaff w ogóle nie zdawał sobie sprawy. Nie o to mianowicie chodzi, czy istniała jakaś ukryta filozofia Leibniza, ani też nie o to, jak dalece Leibniz skłonny był koniunkturalnie zmieniać swoje poglądy w kwestiach politycznych i religijnych ${ }^{87}$. Z filozoficznego punktu widzenia istotne jest to, czy on sam był świadom ukrytych założeń swojego myślenia. Niewątpliwie w rozumieniu i odczuciu Leibniza Bóg wiary i Bóg filozofii to jeden i ten sam Bóg; jest to jednak Byt wydedukowany z umysłu filozofa. Leibniz poznaje Boga intelektualnie, wychodząc od

reflessione leibniziana, w: Leibniz, Saggi di teodicea (Cinisello Balsamo Edizioni San Paolo, 1994), 13.

${ }^{85}$ „There is some question as to whether this letter is genuine. It does not appear in any of the known collections of Leibniz materials. [...] On the other hand, there is nothing that we know about Professor Pfaff to suggest he would fabricate letters of his late friend"; Richard H. Popkin, The History of Scepticism. From Savonarola to Bayle (New York: Oxford University Press, 2003), 268.

${ }^{86}$ "Leibniz's study of the relationship between reason and faith is geared towards calling into question the very bases of these presuppositions. He ultimately comes to the conclusion that reason is necessary to faith and in no way opposed to it. In sum, for Leibniz, the God of the philosophers and the God of faith are one and the same. Indeed, anyone who opposes the one to the other (i.e. any proponent of fideism) is falling away from the true faith"; Andrea Poma, The Impossibility and Necessity of Theodicy. The "Essais" of Leibniz (Dordrecht: Springer, 2013), 85 (oryginał włoski: Impossibilita e necessita della Teodicea. Gli "Essais" di Leibniz, Mursia 1995).

${ }^{87}$ O skłonności Leibniza do oportunizmu, ale i do zwyczajnego zakłamania, zob. Matthew Stewart, The Courtier and the Heretic. Leibniz, Spinoza, and the Fate of God in the Modern World (New York - London: W. W. Norton \& Company, 2006), szczególnie strony 109-120. Zwróćmy uwagę na mocne twierdzenie: „The alarming fact about Leibniz is not that he did not always tell the truth, but that he was, in a certain sense, constitutionally - or perhaps metaphysically - incapable of telling the truth"; tamże, 118. 
przesłanek, które znajduje w swym umyśle, a więc i wnioski, do których dochodzi, a które opisują naturę Boga, należą do jego umysłu. Jego świadomość tych przesłanek jest tak mocna i niepowątpiewalna, jak kartezjańska samoświadomość. Dlatego Leibniz nie może uświadomić sobie, że Boga tworzy, a nie poznaje; mówiąc po kartezjańsku: nie uświadamia sobie, że jego idea Boga to idea skonstruowana ${ }^{88}$. Nie jest więc też świadom, że jego rozważania o Bogu to jedynie gra intelektualna.

Cóż mógłby o tym sądzić Voltaire? Swoje rozważania o tym, czym jest idea, zakończył taką oto sokratejską z ducha refleksją: „To smutne posiadać tak wiele idej, a nie znać dokładnie natury idej. Przyznaję to; wszelako jeszcze smutniejsze i jeszcze bardziej głupie jest wierzyć, że się wie to, czego się nie wie" ${ }^{\prime 9}$. Odnosił to jednak ogólnie do filozofów, nie zaś konkretnie do Leibniza. Zresztą Leibniz nie zrozumiałby, że to także do niego się odnosi. Albowiem genialny umysł filozofa jest zdeterminowany i ograniczony swoją genialnością - i to właśnie stanowi o jego wielkości ${ }^{90}$.

\section{Bibliografia}

Acta Eruditorum anno MDCCXXVIII publicata, Lipsiae: Typis Bernhardi Christoph. Breitkopfii, 1728.

Adams Robert, Merrihew. 1994. Leibniz. Determinist, Theist, Idealist, New York Oxford: Oxford University Press.

Baczko Bronisław, red. 1961. Filozofia francuskiego Oświecenia. Warszawa: PWN.

${ }^{88}$ W Medytacji trzeciej Descartes przedstawia podział idei na wrodzone (np. prawda), nabyte (np. ciepło) i skonstruowane (np. syrena). W jednym z listów wyjaśnił, że konstruując dowody na istnienie Boga m.in. po to, aby przeciwstawić się stanowisku, że „idea Boga jest utworzona przez nas"; List do Clerseliera z 23 kwietnia 1649 r., w: René Descartes, Oeuvres, red. Charles Adam i Paul Tannery (Paris: Libraire J. Vrin, 1974), t. V, 354.

89 „Il est bien triste d'avoir tant d'idées, et de ne savoir pas au juste la nature des idées. Je l'avoue; mais il est bien plus triste et beaucoup plus sot de croire ce qu'on ne sait pas"; Voltaire, Dictionnaire philosophique, 236.

${ }^{90}$ Dopowiedzmy: to dlatego genialny filozof nie potrafi zrozumieć ani tego, że ktoś może odrzucać założenia jego systemu, ani tego, że ktoś może przyjmować inne założenia, niż on przyjmuje. S. Cichowicz w notce redakcyjnej do tekstu wskazanego wyżej w przypisie 65 pisze, że tekst ten „jest świadectwem filozoficznego zaślepienia na odmienność projektów cudzych”; w: Leibniz, Wyznanie wiary filozofa, 505. 
Boutroux Émile. 1880. Notice sur la vie et la philosophie de Leibnitz. W: Leibnitz. La Monadologie. Paris: Delagrave.

Brooks Richard, A. 1964. Voltaire and Leibniz. Genève: Librairie Droz.

Cione Edmondo. 1964. Leibniz. Napoli: Libreria Scientifica Editrice.

Clarke Samuel. 1717. A Collection of Papers which passed between the Late Learned Mr. Leibnitz and Dr. Clarke... London: printed for James Knapton, at the Crown in St. Paul's Church-Yard.

Descartes René. 1974. Oeuvres, red. Charles Adam i Paul Tannery, Paris: Libraire J. Vrin.

Descartes René. 1958. Medytacje o pierwszej filozofii, tłum. Maria i Kazimierz Ajdukiewiczowie i in. Warszawa: PWN.

Descartes René. 2005. Zarzuty i odpowiedzi późniejsze, tłum. Jerzy Kopania. Kęty: Wydawnictwo Antyk.

Gilson Étienne. 1982. Bóg i filozofia, tłum. Maria Kochanowska. Warszawa: Pax.

Gordon Mieczysław. 1974. Leibniz. Warszawa: Wiedza Powszechna.

Gordon Mieczysław. 1985. „O krytyce przez Leibniza kartezjańskiej wersji dualizmu”. Studia Philosophiae Christianae 21 (1): 23-38.

Grover Stephen. 1996. "West Or Best? Sufficient Reason in the Leibniz-Clarke Correspondence”. Studia Leibnitiana 28 (1): 84-92.

Guitton Jean. 1973. Profile, tłum. Ada Borkowska-Szuba, Stanisław Cichowicz, Wanda Sukiennicka. Warszawa: Instytut Wydawniczy Pax.

Guhrauer Gottschalk Eduard. 1842. Gottfried Wilhelm, Freiherr v. Leibnitz. Eine Biographie. Breslau: Hirt; reprint: Hildesheim: Olms 1966.

Kołakowski Leszek. 1988. Jeśli Boga nie ma, tłum. Tadeusz Baszniak i Maciej Panufnik. Kraków: Wydawnictwo Znak.

Krauze-Błachowicz Krystyna. 1992. Leibniz. Wczesne pojęcie substancji. Białystok: Zakład Teorii Poznania. Filia Uniwersytetu Warszawskiego.

Leibniz Gottfried Wilhelm. 1890. Dialogus. W: Carl Immanuel Gerhardt, red. Die Philosophischen Schriften von G. W. Leibniz. T. VII. Berlin: Weidmann.

Leibniz Gottfried Wilhelm. 1955. Nowe rozważania dotyczące rozumu ludzkiego, tłum. Izydora Dąmbska. Warszawa: PWN.

Leibniz Gottfried Wilhelm. 1969. Zasady filozofii, czyli monadologia, tłum. Stanisław Cichowicz. W: Gottfried Wilhelm Leibniz, Wyznanie wiary filozofa. Rozprawa Metafizyczna. Monadologia. Zasady natury i łaski oraz inne pisma filozoficzne, tłum. Stanisław Cichowicz, Juliusz Domański, Henryk Krzeczkowski, Henryk Moese, oprac. Stanisław Cichowicz. Warszawa: PWN.

Leibniz Gottfried Wilhelm. 1969. Wyznanie wiary filozofa, tłum. Juliusz Domański. W: Gottfried Wilhelm Leibniz, Wyznanie wiary filozofa. Rozprawa Metafizyczna. Monadologia. Zasady natury i łaski oraz inne pisma filozoficzne, tłum. Stanisław Cichowicz, Juliusz Domański, Henryk Krzeczkowski, Henryk Moese, oprac. Stanisław Cichowicz. Warszawa: PWN. 
Leibniz Gottfried Wilhelm. 1994. Pisma z teologii mistycznej, tłum. Małgorzata Frankiewicz. Kraków: Wydawnictwo Znak.

Leibniz Gottfried Wilhelm. 2014. „Rozprawa metafizyczna o zasadzie indywiduacji”, tłum. Tomasz Gliński, Studia z Historii Filozofii 5 (3): 35-51.

Leibniz Gottfried Wilhelm. 2001. Teodycea, tłum. Małgorzata Frankiewicz. Warszawa: PWN.

Lovejoy Arthur Oncken. 1999. Wielki łańcuch bytu. Studium z dziejów idei, tłum. Artur Przybysławski. Warszawa: Wydawnictwo KR.

Mackie John Milton. 1845. Life of Godfrey William von Leibnitz; on the basis of the German work of Dr. G. E. Guhrauer. Boston: Gould, Kendall and Lincoln. (Przedruki późniejsze: Kessinger Publishing, 2007 i Leopold Classic Library, 2015.)

Mates Benson. 1986. The Philosophy of Leibniz. Metaphysics and Language. New York - Oxford: Oxford University Press.

Mathieu Vittorio. 1994. Saggiointroduttivo. La conciliazione di ragione e fede punto culminante della reflessione leibniziana. W: Leibniz, Saggi di teodicea. Cinisello Balsamo (Milano): Edizioni San Paolo.

Mercer Christia. 2006. "Leibniz on Mathematics, Methodology and the Good: A Reconsideration of the Place of Mathematics in Leibniz's Philosophy". Early Science and Medicine 11 (4): 424-454.

Mugnai Massimo. 2001. “Leibniz on Individuation: From the Early Years to the „Discourse" and Beyond". Studia Leibnitiana 33 (1): 35-56.

Poma Andrea. 2013. The Impossibility and Necessity of Theodicy. The "Essais" of Leibniz. Dordrecht: Springer. (Oryginał włoski: Impossibilita e necessita della Teodicea. Gli "Essais"di Leibniz, Mursia 1995.)

Popkin Richard H. 2003. The History of Scepticism. From Savonarola to Bayle. New York: Oxford University Press.

Recueil de diverses pieces sur la philosophie, la religion naturelle, l'histoire, les mathematiques, etc., par Mrs Leibniz, Clarke, Newton et autres autheurs célebres, t. I i II. Amsterdam: Duvillard et Changuion 1720 (wyd. 2: 1740).

Russell Bertrand. 2000. Dzieje filozofi Zachodu, tłum. Adam Lipszyc, Tadeusz Baszniak i inni. Warszawa: Fundacja Aletheia.

Stewart Matthew. 2006. The Courtier and the Heretic. Leibniz, Spinoza, and the Fate of God in the Modern World. New York - London: W. W. Norton \& Company.

Tomasz z Akwinu. Quaestiones disputatae de potentia Dei. W: S. Thomae Aquinatis, Opera Omnia. T. 8. Parmae: P. Fiaccadori 1852-1873.

Wittgenstein Ludwig. 1970. Tractatus logico-philosophicus, tłum. Bogusław Wolniewicz. Warszawa: PWN.

Voltaire. 1954. Dictionnaire philosophique. Paris: Éditions Garnier Frères.

Voltaire. 1956. Elementy filozofii Newtona, tłum. Helena Konczewska. Warszawa: PWN.

Voltaire. 2009. Le philosophe ignorant. Paris: Éditions Flammarion. 
Voltaire. 2015. Słownik filozoficzny, tłum. Marian Skrzypek. Warszawa: Fundacja Augusta hr. Cieszkowskiego.

Wolter. 1994. Pamiętniki, tłum. Stanisław Fiszer. Warszawa: Książka i Wiedza.

Yakira Elhanan. 2012. "Time and Space, Science and Philosophy in Leibniz-Clarke Correspondence", Studia Leibnitiana 44 (1): 14-32.

\begin{abstract}
Leibniz and his God. Considerations with Voltaire in the Background

Leibniz was a great philosopher - it is a statement which has grounds in the great philosophical system he created. It begins with God - the basis of the system, and two principles: the principle of sufficient reason and the principle of non-contradiction. Using these two principles, Leibniz creates his God - eternal and unchanging like his principles, determined by the principles and acting within a frame created by them. Leibniz created God in the image and likeness of his own mind - his God possesses an infinite degree of all the attributes of his mind - and only those attributes. This interpretation becomes apparent in Voltaire's critique. Voltaire contrasts the logical conception of God presented by Leibniz with his own conviction of the impossibility of understanding the sense of human existence, and the experience of the limitations of the human mind. Leibniz's God is tailored to the genius mind of the philosopher; Voltaire is not able to comprehend this God because of the limitations of his ordinary human mind. Leibniz's God is the creation of the brilliant mind of the great philosopher - a concept characterized by perfection which cannot exist in reality.
\end{abstract}

Keywords: Leibniz, Voltaire, God, principle of sufficient reason, principle of noncontradiction

\title{
Streszczenie
}

\section{Leibniz i jego Bóg. Rozważania z Voltaire’em w tle}

Leibniz był wielkim filozofem, o czym świadczy stworzony przez niego wielki system filozoficzny. Podstawą tego systemu jest Bóg, a punktem wyjścia dwie zasady: racji dostatecznej i niesprzeczności. Za pomocą tych dwu zasad Leibniz stwarza swego Boga - wiecznego i niezmiennego jak one, zdeterminowanego nimi i działającego w ich ramach. Leibniz stworzył Boga na obraz i podobieństwo własnego umysłu Bóg ten posiada w stopniu nieskończonym wszystkie i tylko te właściwości, które posiada umysł Leibniza. Staje się to widoczne w świetle krytyki dokonanej przez 
Voltaire’a. Logicznemu pojęciu Leibnizowskiego Boga przeciwstawił Voltaire swoje własne odczucie niemożności zrozumienia sensu ludzkiej egzystencji, doświadczenie ograniczoności ludzkiego rozumu. Bóg Leibniza jest na miarę genialnego umysłu filozofa; Voltaire nie jest zdolny pojąć tego Boga, ponieważ ma tylko zwyczajny, ludzki umysł. Bóg Leibniza to twór genialnego umysłu wielkiego filozofa - idea zawierająca w swej treści wszystkie doskonałości, której jednak nie przysługuje realne istnienie.

Słowa kluczowe: Leibniz, Voltaire, Bóg, zasada racji dostatecznej, zasada niesprzeczności 